\title{
Anticipating future risk in social-ecological systems using fuzzy cognitive mapping: the case of wildfire in the Chiquitania, Bolivia
}

\author{
$\underline{\text { Tahia Devisscher }}^{1,2}$, Emily Boyd $^{3,4}$ and Yadvinder Malhi ${ }^{1}$
}

\begin{abstract}
Understanding complex social-ecological systems, and anticipating how they may respond to rapid change, requires an approach that incorporates environmental, social, economic, and policy factors, usually in a context of fragmented data availability. We employed fuzzy cognitive mapping (FCM) to integrate these factors in the assessment of future wildfire risk in the Chiquitania region, Bolivia. In this region, dealing with wildfires is becoming increasingly challenging because of reinforcing feedbacks between multiple drivers. We conducted semistructured interviews and constructed different FCMs in focus groups to understand the regional dynamics of wildfire from diverse perspectives. We used FCM modelling to evaluate possible adaptation scenarios in the context of future drier climatic conditions. Scenarios also considered possible failure to respond in time to the emergent risk. This approach proved of great potential to support decision making for risk management. It helped identify key forcing variables and generate insights into potential risks and trade-offs of different strategies. The "Hands-off" scenario resulted in amplified impacts driven by intensifying trends, affecting particularly the agricultural production under drought conditions. The "Fire management" scenario, which adopted a bottom-up approach to improve controlled burning, showed less trade-offs between wildfire risk reduction and production compared with the "Fire suppression" scenario. Findings highlighted the importance of considering strategies that involve all actors who use fire, and the need to nest these strategies for a more systemic approach to manage wildfire risk. The FCM model could be used as a decisionsupport tool and serve as a "boundary object" to facilitate collaboration and integration of different perceptions of fire in the region. This approach also has the potential to inform decisions in other dynamic frontier landscapes around the world that are facing increased risk of large wildfires.
\end{abstract}

Key Words: adaptation; climate change; complexity; scenario; social-ecological system; uncertainty; wildfire risk

\section{INTRODUCTION}

Forest fires are likely to become more dominant in Amazonia because of increasing feedbacks between rapid frontier expansion and droughts (Cochrane and Laurence 2008, Lee et al. 2011, Davidson et al. 2012, Brando et al. 2014). The 2010 severe drought in this region can be considered a proxy to examine the impacts of reduced precipitation and higher temperatures than average (Lewis et al. 2011, Saatchi et al. 2013, Anderson et al. 2015). This and other recent widespread droughts have contributed to higher susceptibility of forests to wildfire during the dry season (Lee et al. 2011, Brando et al. 2014), and in the future this could be further exacerbated by increased moisture stress (Cox et al. 2004, Christensen et al. 2007, Williams et al. 2007), rapid land use change, logging, and spreading use of fire (Alencar et al. 2004, Nepstad et al. 2004, Aragão et al. 2008, Barlow et al. 2012).

Despite increasing efforts in studying the feedbacks between climate, fire, and land use change, understanding these dynamics and future wildfire risk remains challenging. This partly relates to (i) uncertainty linked to internal variability within the wildfire system, (ii) unknown future behavior of fire use, (iii) multiple forcing functions of biophysical and anthropogenic origin that influence the dynamics of wildfire, and (iv) nonlinear effects caused by these interacting drivers. When the variables and feedbacks in a system are highly uncertain and to large extent difficult to control, it may be more appropriate to consider a variety of possible future scenarios that include main uncertainties rather than to focus on an accurate prediction of a single outcome (Peterson et al. 2003). Scenarios would represent alternatives that capture uncertainty about the future of a system, and provide insights into drivers of change, implications of current trajectories, and different options for action (Peterson et al. 2003).

Fuzzy cognitive mapping (FCM) is an approach with great potential to study complex systems in the context of rapid change, develop relevant plausible scenarios, and assess options to deal with future risk. Indeed, the ability to include variables and dynamics that are highly uncertain is one of the strengths of FCM (Özesmi and Özesmi 2004). For these reasons, we decided to use FCM to explore possible future scenarios of wildfire risk. In addition, the use of FCM is more appropriate in data-poor environments where quantitative scientific information is limited and expensive, but local expert knowledge is extensive and available (Reckien 2014).

The FCM method has been used in different fields, particularly in engineering, social and political sciences. A recent review (Papageorgiou 2011) found that FCM applications have increased significantly in the last decade, and more methodological efforts have enhanced its applicability in different domains. In ecosystem management, the first large-scale ecological application of FCM was published by Hobbs et al. (2002). Since then FCM has been applied to address various ecosystem management objectives including lake management (Hobbs et al. 2002, Özesmi and Özesmi 2003), water resources conflict resolution (Giordano et al. 2005), agro-ecosystem management (Rajaram and Das 2010), species management (Dexter et al. 2012), and forest management (Mendoza and Prabhu 2006, Kok 2009, Soler et al. 2012). More recent studies in environmental management have used FCM to 
address questions of livelihood vulnerability to hazards (Murungweni et al. 2011), knowledge on structure and function of social-ecological systems (Gray et al. 2012), ways to support adaptive environmental management (Gray et al. 2013), climate change impacts and adaptation planning (Reckien 2014), and community disaster planning and social learning (Henly-Shepard et al. 2015).

In this study, we applied FCM to adopt a social-ecological systems approach for wildfire risk management at the regional level, considering climate change. Wildfire risk is defined as the probability of wildfire occurrence (Hardy 2005). In the FCM application context, a high value of the "wildfire" variable was interpreted as high wildfire risk. FCMs were constructed in focus groups and combined with semistructured interviews to advance the understanding of social and ecological dynamics of wildfire, and evaluate possible ways to anticipate and respond to increased wildfire risk under drier climatic conditions. This application is novel in its contextual development and its analysis informed by interview insights.

To ground our findings, we focused on the Chiquitania region located in the Department of Santa Cruz, Bolivia, at the southern edge of Amazonia. This region has a long history and tradition of fire use, but accelerated land use change since the 1980s (Pacheco and Mertens 2004, Killeen et al. 2008) has resulted in the spread of fire use into new forest frontiers and an increase in wildfires (Peredo-Videa 2011, Redo et al. 2011). Recent devastating wildfires are also associated with droughts. Wildfires during the 2010 severe drought burned 1.9 million ha of forest in Santa Cruz (Rodriguez-Montellano 2014). The 2010 wildfires resulted in a national state of emergency, which has intensified public debate around wildfires, looking for tangible solutions to prevent potential impacts, particularly given the possibility of more frequent droughts in the future (Ibarnegaray et al. 2014). According to regional and global climate model projections, seasonality may become more extreme in the region, with less precipitation during the drier months from July to November (Seiler 2009, Seiler et al. 2013). Since the 1990s, Marengo et al. (2011) also identified a tendency for a prolonged dry season in southern Amazonia, with a late onset in the wet season.

The 2010 wildfire crisis motivated a shift in the regional approach to address wildfires. New anticipatory risk strategies were considered moving away from command-and-control measures whose efficacy had proven limited. These anticipatory strategies do not focus on mitigating the impact, but rather on proactively addressing the root causes to prevent wildfire impacts in the future. The anticipatory strategies also differ from previous strategies applied in the Chiquitania in that they try to incorporate the knowledge and participation of local actors who traditionally use fire.

Proactively considering future risk is a form of adaptation whereby adaptation is not only reactive but is also anticipatory or planned (Smit and Wandel 2006, Chapin et al. 2009). Adaptation can either reduce exposure to a hazard, i.e., by containing or controlling it, or decrease susceptibility and increase the capacity to cope, adapt, or benefit from the effects of a hazard (or multiple hazards) with a wide range of possible actions, including those taken before and after the impacts are felt (IPCC 2001, Pelling 2011). The new strategies to reduce wildfire risk in the Chiquitania focus on both decreasing fire use (exposure) and building capacity to better manage fire. By doing so, they anticipate for future events that can trigger change in the coupled social-ecological system (Boyd 2008, Boyd et al. 2015).

Nuttall (2010) describes anticipation as being about foresight, and a prerequisite for thinking about adaptation. Anticipatory practice can take different forms but anticipation potentially helps to raise awareness about possible futures and can sensitize society to the consequences of choices and actions of individuals and societies (Poli 2010). Quay (2010) highlights that anticipatory practices include foreseeing a range of possible futures, including assuming that observed trends will continue, and this can help build the adaptive capacity to respond to events at early rather than later stages of their occurrence, when they may result in crisis. In this study we build on these concepts of anticipation and adaptation, and also recognize that the links between adaptation, risk management, and disaster risk reduction have been tackled by a number of scholars (Schipper and Pelling 2006, O'Brien et al. 2008, Patt and Schröter 2008, Field et al. 2012, O'Brien and Barnett 2013, among others).

Furthermore, Leach et al. $(2007,2010)$ point out that, when analyzing how systems change over time, it is important to pay attention to the multiple ways in which different actors may frame their understandings of the past, of present changes and why they matter, and of future possibilities of change. To take this into account, we examined plausible future scenarios by bringing together a range of actors with different perspectives of fire and visions of the future in the Chiquitania. In the region the scientific information on the wildfire system is growing but is still fragmented. However, the historical use of fire in the Chiquitania has created a vast pool of traditional knowledge on the ecological and social dimensions of fire (McDaniel et al. 2005, Pinto and Vroomans 2007). The combination of FCM and interviews aims to capture this rich body of knowledge.

The scenarios analyzed in this study not only considered alternative approaches to anticipate future wildfire risk, but also possible failure to do so. We assessed all scenarios in the context of climate change, assuming more frequent droughts, i.e., more prolonged dry periods. Given the importance and benefits of using fire for rural production in the Chiquitania, outcomes from plausible scenarios were evaluated in terms of trade-offs between wildfire risk reduction and production of agriculture and livestock. The following questions guided the research:

1. What variables are perceived to have an effect on wildfire occurrence in the Chiquitania, and how do these variables interact?

2. What could be the outcome of a "hands-off" approach assuming current trends intensify in the future?

3. Under drier climatic conditions, what anticipatory strategies could help reduce and better manage wildfire risk?

\section{METHODS}

Brief description of study sites, actors, and fire use

The Chiquitano dry forest ecoregion extends over Bolivia, Brazil, and Paraguay, and links the Amazon rainforests to the north with the Gran Chaco shrublands to the south (Fig. 1). To promote 
conservation of this forest in Bolivia, most of this region was recognized in 2005 as a "Model Forest" (IMFN 2013) covering more than 20 million ha in the Department of Santa Cruz (Vides et al. 2007, Justiniano et al. 2014). Model Forests are established based on an approach that seeks inclusive and participatory processes to integrate the social, cultural, and economic needs of local people with the long-term sustainability and conservation of large forest landscapes (IMFN 2011, RIABM 2015).

Fig. 1. Our two study sites and the four communities interviewed in the Municipalities of Concepción and Roboré, Department of Santa Cruz, Bolivia. The boundaries of the Chiquitano Model Forest are delimited in red (IMFN 2013).

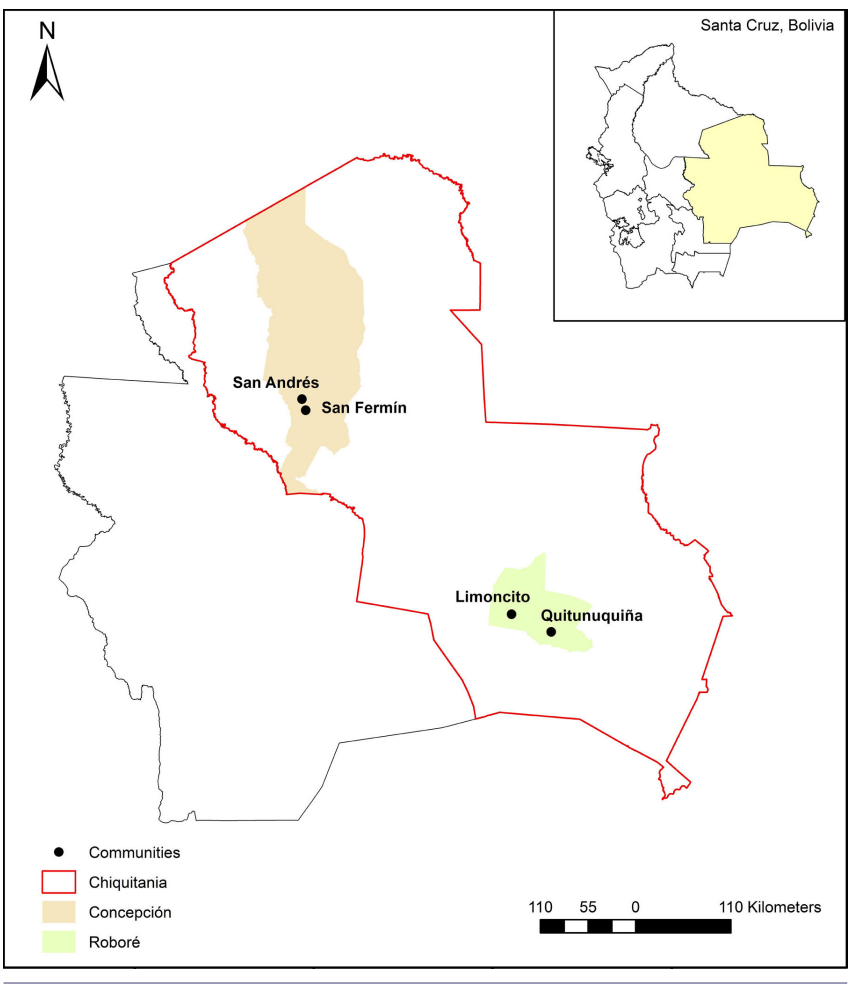

The natural vegetation in the Chiquitania is characterized by tropical dry forest with semideciduous canopy trees, intertwined with grasslands and shrubbery of the woody savanna Cerrado (Killeen et al. 1998). The regional climate is marked by a dry season with an average of six months a year (starting in April/ May) receiving $<100 \mathrm{~mm} \mathrm{month}^{-1}$, of which the driest months are July and August. Given the size of the region, two representative study sites were selected (Fig. 1). One is the Municipality of Concepción, in the transition zone between the Chiquitano dry forest and the Amazon rainforest; the other is the Municipality of Roboré, in the transition zone between the dry forest and the Chaco.

The case study municipalities show a similar land cover and land use configuration to the region. About $54 \%$ of the Chiquitania is covered by seasonally dry tropical forest. This forest type covers $55 \%$ of the Municipality of Concepción and $65 \%$ of Roboré (UTNIT 2010). Land tenure in the Chiquitania region is concentrated in the livestock sector, with properties varying in size from 50 to $50,000 \mathrm{ha}$. The livestock sector contributes to about
$90 \%$ of the regional economy together with the forestry sector (Vides et al. 2007). By 2010 land used for cattle ranching, including some mixed agriculture and agro-forestry, extended over most of the region and the selected case study municipalities, covering about $80 \%$ of the Chiquitania, $63 \%$ of Concepción, and almost $95 \%$ of Roboré (UTNIT 2010). The land used for mixed and commercial agriculture by 2010 was equivalent to $3 \%$ of the Chiquitania, $3 \%$ of Concepción, and $1.5 \%$ of Roboré.

The use of fire for agriculture and cattle ranching is common practice across the Chiquitania (McDaniel et al. 2005). Different types of actors use fire for subsistence and commercial production in Concepción and Roboré. We focused mainly on two actor types, which represent the largest population of fire users in both municipalities and can be broadly categorized as local communities and cattle ranchers.

There are different types of local communities in Concepción and Roboré. Most are indigenous communities inhabited mainly by the Chiquitano people, which is the largest indigenous group in the Chiquitania. Several indigenous communities were founded between the 1950s and 1980s after the Agrarian Reform. During this time, some communities mixed with immigrants from other parts of the country, and more communities were established as a result of planned and spontaneous colonization in the context of import substitution policies (Pacheco and Mertens 2004). Since the mid-2000s, a new colonization is taking place in the region driven by postneoliberalism policies introduced by the state, which is actively identifying fiscal land for distribution (Redo et al. 2011). This recent colonization is expanding into Concepción and Roboré. This has led to new settlements known as intercultural communities inhabited by immigrants from different cultures and regions of Bolivia.

Indigenous communities in Concepción and Roboré practice mainly shifting cultivation for subsistence with some cash crops for trade, whereas intercultural communities produce primarily for commerce. Slash and burn agriculture is predominant in all cases, and the use of mechanization is currently minimal. Fire is used to clear forestland for agriculture ("conversion fire"), but also to burn waste, to cook in the households and during hunting, and to manage small-scale natural grasslands and cultivated pastures for cattle ("maintenance fire").

In the 1990s, deforestation accelerated in the Chiquitania because of neoliberal structural reforms to boost the country's economy (Pacheco and Mertens 2004, Killeen et al. 2008, Peredo-Videa 2008). Private landholdings, such as cattle ranches in Concepción and Roboré, proliferated during this period. Since 2000, the livestock sector has been the principal cause of land cover change in the lowlands of Bolivia, representing about $50 \%$ of the deforestation and impacting particularly the Chiquitania (Müller et al. 2014). Private small, medium, and large cattle ranchers are categorized according to the number of cattle they own and not their property size. The categorization is estimated in relation to the total number of cattle in a specific municipality.

Large private cattle ranchers generally use mechanized clearing to expand and maintain their production, whereas small cattle ranchers use mainly manual clearing and maintenance. Depending on their size and resource availability, medium private cattle ranchers may use mechanized clearing, but in most 
instances they hire manual labor to clear land for pastures using conversion fire. To varying degrees, private cattle ranchers use maintenance fire to manage their pastures, which includes removing invasive species, facilitating grass regeneration, and eliminating pests. Maintenance fire is conducted on a periodic basis varying from every one to five years.

\section{Semistructured interviews}

We conducted in-depth, semistructured interviews aimed at understanding current fire use practices and conditions, local perceptions on wildfire including causes and impacts, observed changes over time, and prevailing wildfire risk strategies. Interview questions for local and regional authorities also aimed at eliciting their future visions for the Municipalities of Concepción and Roboré. The interviews were implemented prior to the FCM method. The responses helped us prepare the facilitation of the focus groups to construct the FCMs. Interview responses were also key to inform the assumptions used for scenario development and to ground the analysis of the outcomes. Fieldwork was conducted between July and September 2013.

A total of four communities participated in the interviews (Fig. 1). We conducted 10 semistructured interviews in each community (total 40 interviews) selected on predefined criteria (Table A1.1). In Roboré, the selected communities were engaged since 2011 in a pilot project to improve fire use practices. Intercultural communities were not included in the interviews, because they were not formally consolidated yet. It was difficult to find people in these communities because they were still moving between their new and their original settlements. In each community, we first organized a community gathering to construct a historical profile and a community map. Household clusters were identified in the community map and a total of 10 households evenly distributed across the different clusters were randomly sampled for the interviews.

Interviews were also conducted with 10 private cattle ranchers in each Municipality (total 20 interviews). The proportion of small, medium, and large cattle ranchers we interviewed in each site was according to the distribution of the cattle rancher population in each category. The local Cattle Rancher Associations, which collected registries with these data, shared with us the following proportions: private large cattle ranchers $(10 \%$ in Concepción, $5 \%$ in Roboré), middle cattle ranchers $(60 \%, 35 \%)$, and small cattle ranchers $(30 \%, 60 \%)$.

Finally, eight representatives of the government were interviewed in Concepción, five in Roboré, and three in Santa Cruz where the departmental government and the regional representation of the Forest and Land Authority (ABT Spanish acronym) are located. In Santa Cruz, interviews were also conducted with the Cattle Rancher Federation, and researchers and practitioners working on wildfire in the Chiquitania.

\section{Construction of the FCMs}

Fuzzy cognitive maps represent causal relationships among variables in a system as defined and described by people (Özesmi and Özesmi 2004, Murungweni et al. 2011). Because the method adopts a participatory approach that involves local actors in building the FCMs, it is considered a more transparent way to build a model, deconstruct and capture tacit knowledge, and represent knowledge diversity (Gray et al. 2012). Furthermore,
FCM provides a flexible approach to include variables of different nature in the analysis. Hobbs et al. (2002) observed that a common difficulty in ecosystem management is that quantitative processbased models rarely address relationships of public concern that are highly uncertain, difficult to quantify, or not accessible. Instead, by building on expert knowledge, semiquantitative FCM can deal with the components of the system that are not well known, and can incorporate relationships yet to be quantified. Although expert knowledge is in itself not sharp and precise (Salski 1992), this approach helps close some of the gap between the development of the model, plausible scenarios, and the public concerns.

The FCMs use fuzzy-graph structures to represent variables, i.e., concepts, and their causal relationships, i.e., directed and weighted connections or edges. The FCM variables can represent logical propositions, state variables, random events, or management decisions (Hobbs et al. 2002). In this study, the FCMs represented local experts' perception of the interactions among the variables that influence, directly or indirectly, the occurrence of wildfires in the Municipalities of Concepción and Roboré. Variables ranged from concepts that could be measured, e.g., deforestation, to more qualitative concepts, e.g., intention to cause fire.

The FCMs were developed in different focus groups, and hence represented stakeholder group knowledge (Özesmi and Özesmi 2004). Overall we facilitated five homogenous focus groups organized by actor type: indigenous communities, private cattle ranchers, local authorities in Concepción, local authorities in Roboré, and regional experts. The last group comprised representatives from the regional government, research institutes, and nongovernmental organizations based in Santa Cruz working on wildfire risk in the Chiquitania. Each focus group engaged five experts, which were selected from the pool of previously interviewed informants based on predefined criteria listed in Table A1.2. Essentially, these criteria helped identify the individuals with most knowledge about the wildfire dynamics in the case study Municipalities and with extensive experience in fire, agriculture and land management.

The steps implemented to construct the group FCMs are illustrated in Figure 2. Prior to the focus group discussions, the interview responses were analyzed to identify a set of variables perceived to have an effect on wildfire occurrence. Variables identified in the interviews with local community farmers were used in the focus group with selected local community experts, variables identified in the interviews with local authorities were used in the focus group with selected local authorities, and the same with the other groups.

The first exercise with the experts in each focus group was to discuss, revise, and if necessary add to the set of preidentified variables before locating them in a circle on a large drafting film (Appendix 2). Next, causal connections (positive and negative) were discussed and directed edges were drawn among the variables. Variables in the system and their connections were evaluated one by one to ensure connections were not missed. Weights in real numbers [-1,1] were given to each connection based on a scale agreed among the experts at the beginning of the exercise. This scale was very similar for all the groups: 0.1 or 0.2 weak, 0.3 light, 0.5 moderate, 0.7 strong, 0.9 or 1 very strong 
connection. The discussion among the experts helped in the interpretation of connections and their weights. During the exercise there was always opportunity to modify the FCM, which required using material that can be easily erased or moved around. To conclude the focus group work, participants discussed prevailing wildfire risk strategies and the effects they could have on the variables in the FCM. Discussions were voice-recorded and used for the analysis.

Fig. 2. Steps implemented for the construction of fuzzy cognitive maps in focus groups. The five expert groups are represented by the five arrows in the flow diagram. The homogeneous focus groups are arranged by actor type: indigenous communities, private cattle ranchers, local authorities in Concepción, local authorities in Roboré, and regional experts. All actors are relevant to wildfire risk management in the Chiquitania region.

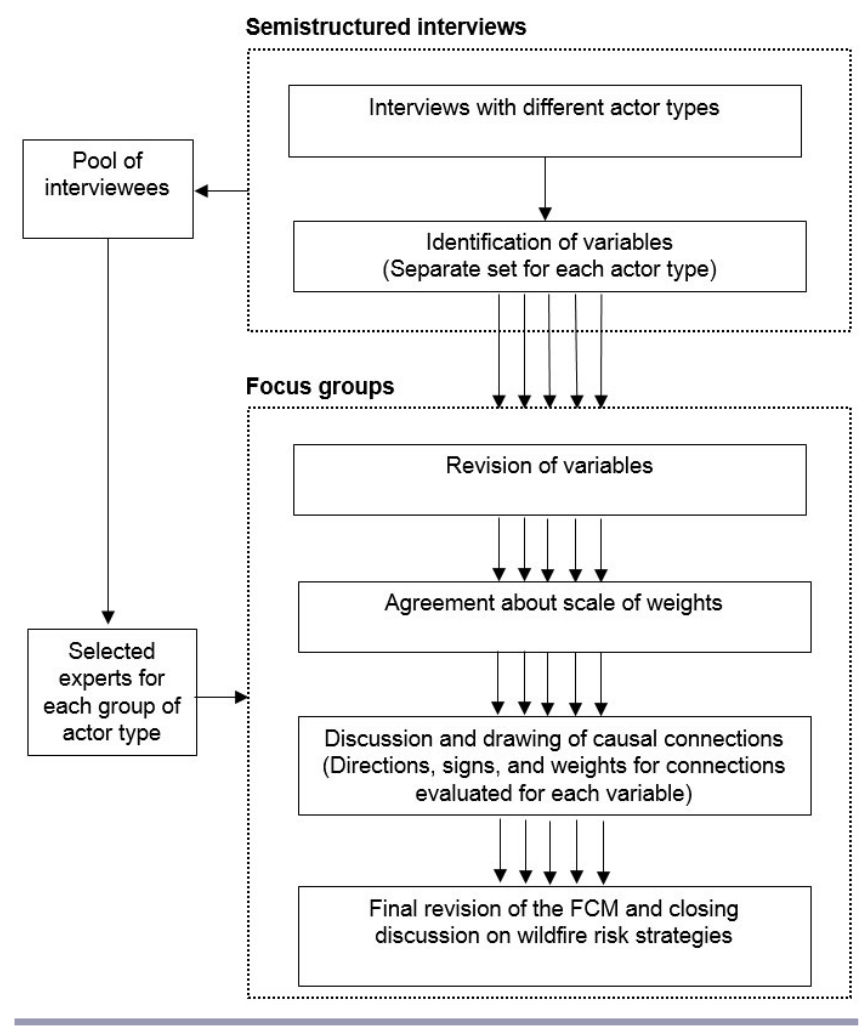

\section{FCM network structure analysis}

The variables and connections mapped in each focus group FCM were entered into adjacency matrices for further analysis (Kosko 1986). Once matrices were coded, the FCM developed by the regional experts was combined with the FCMs from the indigenous communities, cattle ranchers, and local authorities in Concepción to develop an augmented and normalized FCM (Appendix 3) as explained in detail by Kosko (1988). When variables or connections among variables were repeated, the addition of FCMs reinforced fuzzy logic understandings. When variables or connections were not repeated, they were included in the augmented FCM, but they were not reinforced, i.e., they resulted in variables with low state value and weak causal connections. Although the number of variables and connections varied between the group FCMs, edge directions and signs were similar. For this reason the aggregation was straightforward, and matrices were added and averaged at equal credibility weights without conflict in edges.

The adjacency matrices were used to visualize the FCM networks and analyze their structure using different network metrics based on graph theory (Diestel 2005, Newman 2010). First, FCM networks were analyzed in terms of degree centrality to identify key variables for posterior FCM inference (Table 1). Using degree centrality, variables were categorized into (i) central, (ii) transmitters, and (iii) receivers (Özesmi and Özesmi 2004; see definitions in Table 1). Transmitters represent drivers that are relevant to consider in policy or strategy formulation. Receivers or outcome variables were used to monitor and compare the outcomes of possible scenarios (Özesmi and Özesmi 2004). In addition, other structure metrics were calculated to compare connectivity and complexity of the FCMs (Table 1). Most metrics were calculated using igraph in $\mathrm{R}$ v3.0.2 and networks were visualized using NetDraw v2.121.

\section{FCM inferences, sensitivity, and uncertainty analyses}

To generate FCM inferences we used a neural network computational method (Kosko 1992, Özesmi and Özesmi 2004, see more details in Appendix 4). Inferences were generated of what could happen in the system under the given conditions of current relationships, i.e., the baseline, and under a different set of assumptions, i.e., plausible scenarios.

After running the baseline, a first sensitivity analysis was computed on the augmented FCM to assess the effects of varying the state values of transmitter and central variables in the system. Given the high effect of droughts ("prolonged dry periods") on the system as a whole, a second sensitivity analysis was conducted assuming a fixed high state value for "prolonged dry periods" at each run. From this second sensitivity analysis, the few variables that resulted in maintenance or reduction of wildfire occurrence compared to the baseline were selected and combined with interview data to design future scenarios.

Three scenarios were designed to capture possible ways to address increased wildfire risk in the Chiquitania (Table 2). The first scenario, "Hands-off," assumed failure to anticipate future risk by taking a passive approach. An intensification of current trends was associated to this scenario, taking into account recent national interests and policies to expand the agricultural frontier (Fundación Tierra 2015, Government of Bolivia 2015). The "Fire management" and "Fire suppression" scenarios related to two different proactive approaches to deal with future wildfire risk. The Fire management scenario recognized the fire tradition in the Chiquitania and assumed that fire can be better managed. The Fire suppression scenario assumed efforts to eradicate the use of fire by introducing alternative techniques, which concurrently help intensify production practices in the livestock sector.

For the scenario runs, the same procedure of matrix multiplication using the equation in Appendix 4 was computed as with the baseline, except that the values of some variables were manipulated based on assumptions informed by interview results, focus group discussions, and the sensitivity analysis (Table 2). The value of some transmitter variables in the state vector were fixed 
Table 1. Indices for network structure analysis of the fuzzy cognitive maps (FCM).

\begin{tabular}{|c|c|c|}
\hline Structure metrics & Definition & Source \\
\hline Central variables & $\begin{array}{l}\text { Variables with highest degree centrality }{ }^{\dagger} \text { (upper percentile), calculated as the } \\
\text { sum of out degree } o d(v i) \text { and in degree } i d(v i) \text { where } o d(v i) \text { is the row sum of } \\
\text { absolute values of a variable in the adjacency matrix, and } i d(v i) \text { is the column } \\
\text { sum of absolute values of a variable }\end{array}$ & $\begin{array}{l}\text { Özesmi and Özesmi 2004, this } \\
\text { study }\end{array}$ \\
\hline $\begin{array}{l}\text { Forcing functions or } \\
\text { transmitter variables }\end{array}$ & $\begin{array}{l}\text { Variables with zero } i d(v i) \text {. Ordinary transmitters are variables with high } o d(v i) \text { to } \\
i d(v i) \text { ratio (upper percentile) }\end{array}$ & $\begin{array}{l}\text { Özesmi and Özesmi 2004, this } \\
\text { study }\end{array}$ \\
\hline $\begin{array}{l}\text { Outcome variables or receiver } \\
\text { variables }\end{array}$ & $\begin{array}{l}\text { Variables with zero } o d(v i) \text {, and variables with high } i d(v i) \text { to } o d(v i) \text { ratio (upper } \\
\text { percentile) }\end{array}$ & $\begin{array}{l}\text { Özesmi and Özesmi 2004, this } \\
\text { study }\end{array}$ \\
\hline \multirow[t]{2}{*}{ Density $D$} & $\begin{array}{l}\text { Number of edges } E \text { divided by the maximum number of possible edges between } \\
\text { a number } N \text { of variables }\end{array}$ & Wasserman and Faust 1994 \\
\hline & $D=\frac{\mathrm{E}}{\mathrm{N}(\mathrm{N}-1)}$ & \\
\hline Complexity $C$ & $\begin{array}{l}\text { Ratio between number of receiver } R \text { variables to transmitter } T \text { variables } \\
\qquad C=\frac{\mathrm{R}}{\mathrm{T}}\end{array}$ & Özesmi and Özesmi 2004 \\
\hline Average edge weight $W_{\text {avg }}$ & $\begin{array}{l}\text { Total sum of absolute edge weights } W \text { divided by total number of edges } E \\
\qquad W_{\text {avg }}=\frac{\sum \mathrm{W}}{\mathrm{E}}\end{array}$ & Reckien 2014 \\
\hline \multirow[t]{2}{*}{ Hierarchy index $h$} & $\begin{array}{l}\text { Hierarchy index } h \text { depends on the total number } N \text { of variables. When } \mathrm{h} \text { is equal } \\
\text { to } 1 \text { the network is fully hierarchical }\end{array}$ & $\begin{array}{l}\text { MacDonald 1983, Özesmi and } \\
\text { Özesmi } 2004\end{array}$ \\
\hline & $h=\frac{12}{(N-1) N(N+1)} \sum_{i}\left[\frac{o d(v i)-\left(\sum o d(v i)\right)}{N}\right]^{2}$ & \\
\hline
\end{tabular}

Table 2. Scenario design for fuzzy cognitive map (FCM) inference.

\begin{tabular}{|c|c|c|}
\hline Scenario & Brief description & Assumptions \\
\hline Baseline & Current conditions & Given conditions of relationships are maintained \\
\hline Hands-off & $\begin{array}{l}\text { Passive attitude of nonintervention } \\
\text { Intensification of current trends based on national policies } \\
\text { aimed at food security and agreements to expand the } \\
\text { agricultural frontier }\end{array}$ & $\begin{array}{l}\text { Fixed high state value [1] of rapidly growing drivers: "roads," } \\
\text { "medium cattle ranchers," "fiscal land for endowment" }\end{array}$ \\
\hline Fire management & $\begin{array}{l}\text { Collective adoption of improved burning practices to } \\
\text { manage fire through capacity building and awareness } \\
\text { raising } \\
\text { Support: local NGOs, local and regional governments } \\
\text { Combined with enforced regulation to accelerate adoption } \\
\text { Support: ABT, regional and local governments }\end{array}$ & $\begin{array}{l}\text { Decrease in the weight of causal connections }[0.2] \text { between } \\
\text { "burning for regrowth" / "burning for new pastures" / "burning } \\
\text { for new agriculture fields" and "wildfire" } \\
\text { Removal of the causal connection [0] between "hunting" and } \\
\text { "wildfire" } \\
\text { Fixed low state value [0] of "intent to cause fire" }\end{array}$ \\
\hline Fire suppression & $\begin{array}{l}\text { Eradication of fire use with focus on the livestock sector } \\
\text { Replacement with alternative fire-free techniques to } \\
\text { modernize the sector and increase productivity } \\
\text { Support: national and local governments, private and } \\
\text { foreign investments }\end{array}$ & $\begin{array}{l}\text { New "modernization driver" with positive causal connection } \\
{[0.5] \text { to "mechanized deforestation." and [0.7] to "livestock }} \\
\text { yield" } \\
\text { "Modernization driver" with negative causal connection [-0.5] to } \\
\text { "manual deforestation," [-0.9] to "burning for regrowth" and [- } \\
0.7] \text { to "burning for new pastures" }\end{array}$ \\
\hline
\end{tabular}

NOTE: ABT is the Spanish acronym for the Forest and Land Authority. 
during the iterations because they represented drivers that could be manipulated without affecting the structure of the FCM. A new variable ("modernization driver") was introduced to analyze the effect on key central variables in the system. In other instances, the weights of causal connections were manipulated to assume change in the strength of the relationship.

The scenarios were mainly based on assumptions about socioeconomic processes, however it was also necessary to account for the effects of climate change in terms of more severe droughts ("prolonged dry periods"). This was particularly important given the overall systemic effect of this variable revealed by the sensitivity analysis, and the perception shared by many interviewees about dry periods becoming longer and more frequent. To capture this, FCM inferences were computed for each scenario assuming a fixed high state value for "prolonged dry periods."

Because all input and output of FCMs are semiquantitative in nature, information provided in numbers was only analyzed relative to other numbers in the network (Kok 2009, Reckien 2014). Therefore, scenario outcomes were not directly compared with absolute indicators (Reckien 2014) but rather interpreted as a summary of relationships between variables and changes compared to the baseline (Özesmi and Özesmi 2004).

\section{Limitations}

Some drawbacks of the FCM inferences are that (i) they do not generate insights on explicit spatio-temporal dynamics and (ii) they are based on subjective weighting of relationships among variables in the system (Murungweni et al. 2011). To overcome part of the temporal limitation, we followed a suggestion by Kok (2009) whereby the variables included in the FCM operate on a similar temporal scale, in this case on an annual basis. To overcome the subjective weighting of casual connections we (i) involved multiple actors in the coconstruction of the FCM and (ii) conducted an uncertainty analysis to assess the effects of variation in the weights following Murungweni et al. (2011). The uncertainty analysis was performed by varying all the edge weights in the matrix of the FCM within $10 \%$ of their value. For the analysis, 5000 matrices were generated using Latin Hypercube Sampling and run for each scenario. The range of output values provided insight into the robustness of the outcomes (Murungweni et al. 2011).

\section{RESULTS}

Forcing functions, outcome variables, and complexity The structure analysis of the FCM networks generated important insights about key variables and different "mental models" (Gray et al. 2012) of the wildfire system in the Chiquitania. The augmented FCM resulted in a network of 36 variables with 110 edges (Appendix 5). Figure 3 shows the network visualization of the augmented FCM generated from combining the regional experts' FCM and the three group FCMs developed in Concepción (see group FCMs in Appendix 6). In total, 22 variables were common across the group FCMs, equivalent to $60 \%$ of the variables in the augmented network.

The central variables in the augmented FCM were the same as in the group FCMs (Table 3). Central variables are important because they have the greatest capacity to influence the system as a whole. Across all FCMs the central variables ranged between 3 to 5, which showed how people's understanding of complex dynamics tend to focus on fewer important variables, with a larger number of variables playing less of a central role (Fig. 4), Common central variables were "manual deforestation," "livestock production," and "mechanized deforestation," which highlighted the multiple perceived interactions between wildfire, land clearing, and the production systems in the region. As expected, "wildfire" was a common central variable given the research question used to develop the FCMs.

Table 3. Common key variables in the regional (1) and local (3) fuzzy cognitive maps (FCM) of the wildfire system in the Chiquitania.

\begin{tabular}{|c|c|c|c|c|}
\hline & \multirow{2}{*}{$\begin{array}{l}\text { Regional } \\
\text { Experts }\end{array}$} & \multicolumn{3}{|c|}{ Concepción } \\
\hline & & Ranchers & $\begin{array}{l}\text { Commu- } \\
\text { nities }\end{array}$ & Authorities \\
\hline \multicolumn{5}{|l|}{ Central variables } \\
\hline Wildfire & $\mathrm{O}$ & $\mathrm{O}$ & $\mathrm{O}$ & o \\
\hline Manual deforestation & $\mathrm{o}$ & $\mathrm{o}$ & o & o \\
\hline $\begin{array}{l}\text { Mechanized } \\
\text { deforestation }\end{array}$ & $\mathrm{O}$ & $\mathrm{O}$ & $\mathrm{O}$ & \\
\hline Livestock production & $\mathrm{o}$ & $\mathrm{O}$ & & $\mathrm{o}$ \\
\hline \multicolumn{5}{|l|}{ Transmitters } \\
\hline Roads & $\mathrm{o}$ & $\mathrm{O}$ & $\mathrm{o}$ & o \\
\hline Prolonged dry period & $\mathrm{o}$ & $\mathrm{o}$ & o & o \\
\hline Large cattle ranchers & o & o & o & o \\
\hline $\begin{array}{l}\text { Medium cattle } \\
\text { ranchers }\end{array}$ & o & o & o & o \\
\hline $\begin{array}{l}\text { Fiscal land for } \\
\text { endowment }\end{array}$ & $\mathrm{o}$ & $\mathrm{O}$ & & $\mathrm{o}$ \\
\hline Intent to cause fire & $\mathrm{O}$ & & $\mathrm{o}$ & o \\
\hline Small cattle ranchers & o & $\mathrm{O}$ & o & $\mathrm{o}^{\dagger}$ \\
\hline $\begin{array}{l}\text { Indigenous } \\
\text { communities }\end{array}$ & $\mathrm{o}^{\dagger}$ & o & $\mathrm{o}$ & $\mathrm{o}$ \\
\hline $\begin{array}{l}\text { Intercultural } \\
\text { communities }\end{array}$ & $\mathrm{o}^{\dagger}$ & $\mathrm{o}^{\dagger}$ & $\mathrm{o}$ & $\mathrm{o}^{\dagger}$ \\
\hline \multicolumn{5}{|l|}{ Receivers } \\
\hline Livestock production & $\mathrm{o}$ & $\mathrm{O}$ & $\mathrm{o}$ & o \\
\hline $\begin{array}{l}\text { Agricultural } \\
\text { production }\end{array}$ & $\mathrm{o}$ & $\mathrm{o}$ & $\mathrm{o}$ & $\mathrm{o}$ \\
\hline
\end{tabular}

Some variables are common to 3 out of the 4 FCMs

${ }^{\dagger}$ Ordinary transmitters (upper percentile od(vi) to id(vi) ratio)

Most of the transmitters and receivers were also similar among the group FCMs (Table 3). In general, the networks exhibited a large number of transmitters. Some related to variables that local and regional actors in the interviews perceived as exogenous forces that were "out of their control." For instance, "prolonged dry periods" were perceived as a force affecting the system from outside its boundaries, and the development of "roads" or "fiscal land for endowment" were dictated by external top-down decisions led by the national government outside the regional system. However, other transmitters related to agency, represented by different actors that use fire for their production such as private cattle ranchers, indigenous and intercultural communities. Agency was not perceived as an outside force, but instead as an endogenous factor, which has potential to influence wildfire occurrence from within the system boundaries. 
Fig. 3. Network visualization of the augmented fuzzy cognitive map. Node size represents degree centrality where variables with higher degree have larger nodes. Transmitter variables are presented in red and ordinary transmitters in blue. Edge weights are normalized and numbers reduced to one decimal only for visualization (value 0.0 represents 0.03 ).

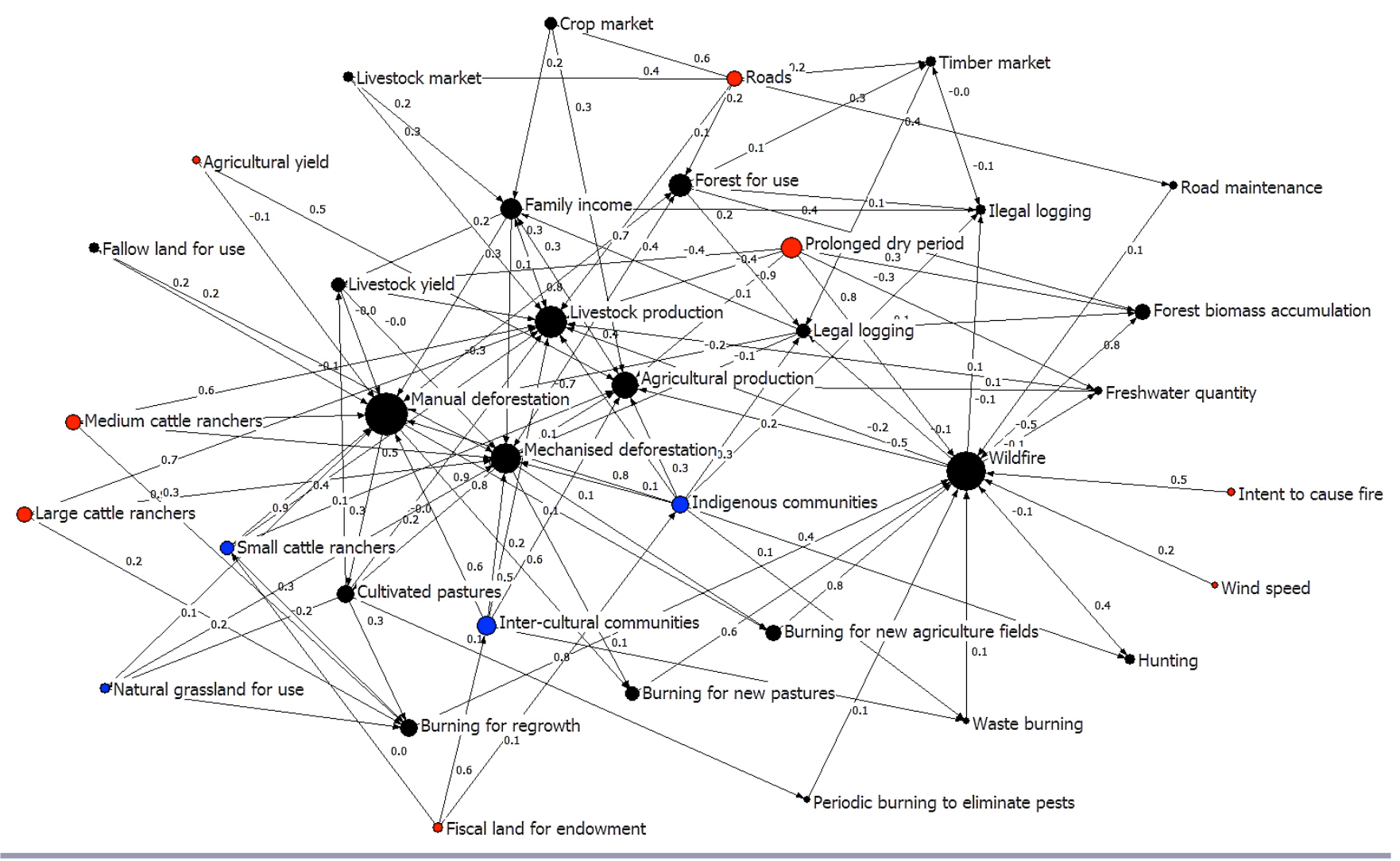

The transmitters also related to the main drivers of wildfire mentioned in interviews. In addition to the common transmitters in Table 3, hunting was mentioned in several interviews. For example, an indigenous farmer explained the different causes of wildfire in Roboré: "Wildfires in the mountains are mainly caused by hunters. Wildfires on this other side are from land clearing. Wildfires are always caused by humans, they are not natural. Even kids used to play and start a fire." In addition to accidental (and intentional) anthropogenic fires, many interviewees indicated that wildfires were closely linked to biomass accumulation and a prolonged seca (local term for dry period).

Although identifying drivers of wildfire is important to formulate strategies that focus on the root causes, it is also necessary to identify outcome variables to monitor and compare the scenario outcomes of possible strategies. The receiver variables in the FCM networks are outcome variables because they are greatly influenced by the other variables in the system. "Livestock production" and "agricultural production" were identified as receivers in all the FCMs; both related to the main purpose of fire use among local communities and cattle ranchers. These two outcome variables were used to evaluate the scenario outcomes in terms of trade-offs, i.e., if strategies could reduce wildfire occurrence without having a detrimental effect on livestock and agriculture production.
We used additional network descriptives to compare structure and complexity results at network level (see Appendix 5). The network complexity was higher in the regional experts' FCM than in the other group FCMs. Overall, the augmented network presented a higher number of connections, lower average weight of total causal connections, lower hierarchy, and a higher edge to node ratio than the group FCMs.

\section{Future wildfire risk anticipation and uncertainty}

Key variables for wildfire risk management

Transmitters were key variables considered in the scenario design. The sensitivity analysis complemented the degree centrality analysis to further narrow down variables with a significant effect on the system as a whole, and on wildfires in particular (Table 4). The transmitter variables with the highest effect on the system were "prolonged dry period," "roads," "medium cattle ranchers," and "large cattle ranchers," followed by "fiscal land for endowment." In the interviews these variables were perceived to be rapidly changing and expected to increase in the future. Several farmers noticed a delay in the offset of rain and referred to prolonged dry periods becoming more frequent and affecting their production. For example, a farmer in Concepción explained, "Since 2000 we have had dry years, we felt the seca more ... The seca has been very long. These have been difficult years for agriculture." Prolonged dry periods were also perceived to increase wildfire risk. 
Fig. 4. Out degree (OD) and in degree (ID) centrality of all variables in the augmented fuzzy cognitive map network. From top to bottom, variables are presented in ascending order based on their degree centrality (sum of OD and ID).

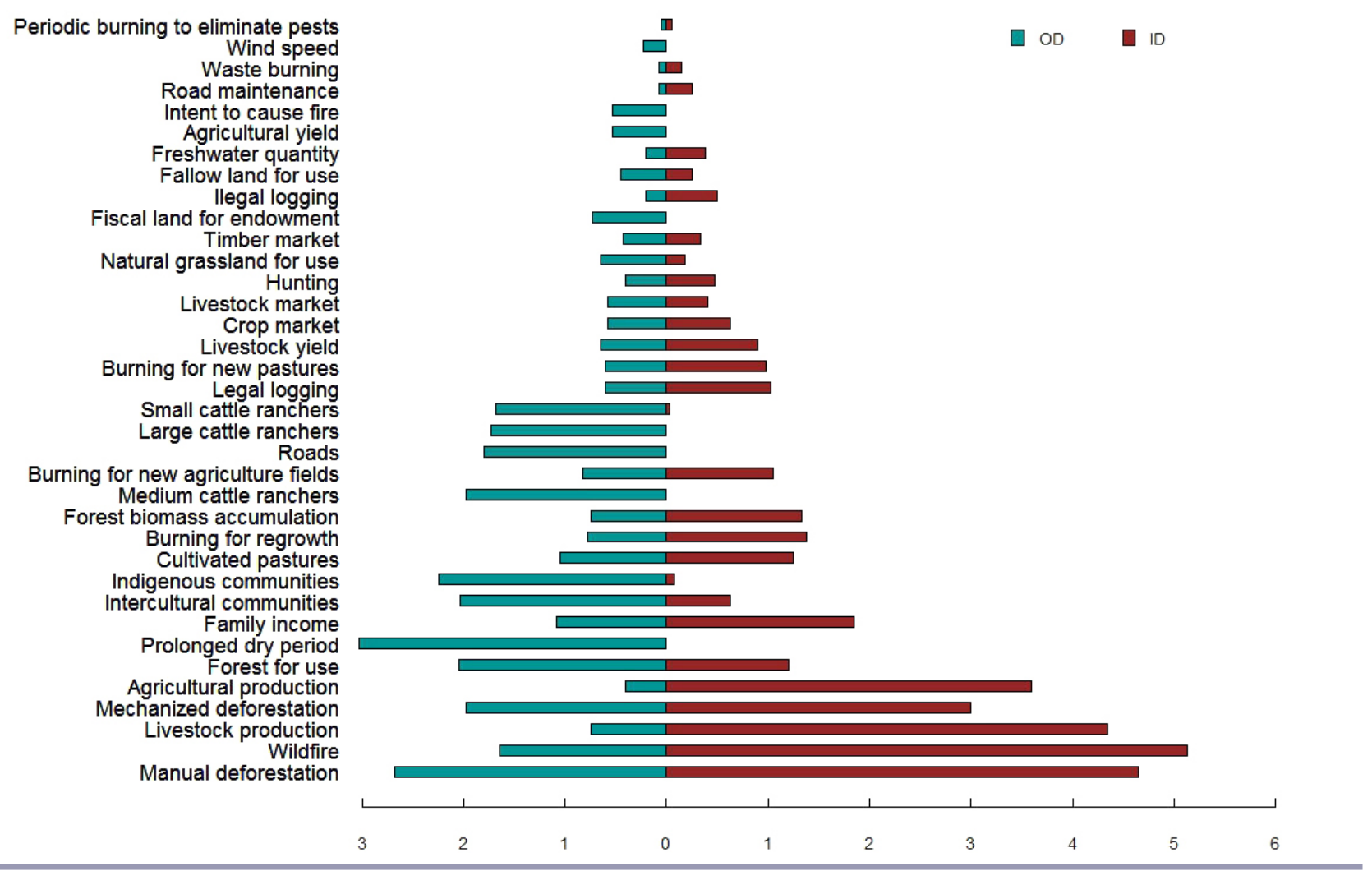

Table 4. Sensitivity analysis on the augmented fuzzy cognitive map. Variables with the highest effect on the system as a whole, and on wildfire occurrence in particular.

\begin{tabular}{|c|c|c|}
\hline & System & Wildfire \\
\hline $\mathrm{C}$ & $\begin{array}{l}\text { Manual deforestation } \\
\text { Mechanized deforestation }\end{array}$ & Manual deforestation \\
\hline \multirow[t]{5}{*}{$\mathrm{T}$} & Prolonged dry period & Prolonged dry period \\
\hline & Roads & Intent to cause fire \\
\hline & Medium cattle ranchers & \\
\hline & Large cattle ranchers & \\
\hline & Fiscal land for endowment & \\
\hline \multirow[t]{3}{*}{ OT } & Indigenous communities & \\
\hline & Intercultural communities & \\
\hline & Small cattle ranchers & \\
\hline \multirow[t]{4}{*}{$\mathrm{OV}$} & & $\begin{array}{l}\text { Burning for new agriculture } \\
\text { fields }\end{array}$ \\
\hline & & Burning for regrowth \\
\hline & & Burning for new pastures \\
\hline & & Hunting \\
\hline \multicolumn{3}{|c|}{ C: central variable } \\
\hline \multicolumn{3}{|c|}{ T: transmitter variable, zero id(vi) } \\
\hline \multicolumn{3}{|c|}{ OT: ordinary transmitter, upper percentile od(vi) to id(vi) ratio } \\
\hline \multicolumn{3}{|c|}{$\begin{array}{l}\text { OV: ordinary variable, but repetitively mentioned in relation to } \\
\text { wildfires in the interviews }\end{array}$} \\
\hline
\end{tabular}

Assuming a fixed high state value for "prolonged dry periods" in the sensitivity analysis, only few variables had high effect on wildfire occurrence. Fixed to a low state value, these variables could maintain or reduce wildfire risk compared to the baseline. Variables that helped maintain the level of wildfire occurrence were "intent to cause fire," "manual deforestation," "hunting," and "burning for new pastures." The only two variables that resulted in wildfire risk reduction were "burning for regrowth" (of natural grass or cultivated pastures) and "burning for new agriculture fields."

\section{Ground perceptions informing scenario assumptions}

The Hands-off scenario assumed failure to anticipate future wildfire risk in the context of intensifying current trends. An increase in roads was assumed based on government plans to improve the transportation network and the perception of local and regional authorities we interviewed, who envisaged rapid economic development and an increase in production in the future. These interviewees also indicated future growth in private cattle ranchers because of the following: (i) the Chiquitania being recently declared a zone free of foot-and-mouth disease, attracting more investment in the livestock sector, (ii) shifting investment from forestry to cattle ranching because of more strict regulations in the forestry sector and more strict enforcement of land policies, and (iii) recent national policies fostering food security and agreements between the national government and the agro-industry sector to boost productivity and expand the 
agricultural frontier in the lowlands of Bolivia to 13 million ha by 2025 (Government of Bolivia 2013, 2015, Fundación Tierra 2015). This scenario also assumed increasing fiscal land endowment, which according to local authorities in Roboré and Concepción would result in more intercultural communities settling in the region, with potential land and cultural conflicts.

The Fire management scenario recognized the fire use tradition in the region, but also the need for a collective change in fire use practice. Adoption of improved burning practices was assumed based on growing awareness about wildfire risk and pilot actions by different fire users. In the interviews, community farmers and private cattle ranchers explained they have been exposed to media campaigns on wildfire prevention since the early 2000s. They also mentioned being "afraid" of fire sanctions, which the ABT had enforced more strictly since the mid-2000s. Although these activities seemed to have raised awareness, change in behavior was perceived mainly in communities that had been exposed to impacts of wildfires in the past, or had participated in training and pilot actions. These trainings were motivated to a large extent by the 2010 wildfire crisis. In the Municipality of Roboré, a pilot project was initiated in 2011 by a local conservation NGO to facilitate coordination of fire management activities. Communities in the project were trained in improved burning techniques and fire control, as well as in monitoring activities to inform a decentralized early warning system. The regional government supported additional trainings to set up a decentralized system of fire brigades. In Concepción, the Municipality started to coordinate similar training on a more adhoc basis.

The Fire suppression scenario considered reducing the use of fire by substituting it with alternative fire-free techniques. In the Chiquitania, these techniques targeted primarily the livestock sector because they have potential to increase its productivity. The assumptions are largely based on a program launched in 2011 by the national government called Amazonia Sin Fuego (Amazonia Without Fire). Demonstration fields are being piloted in the region to show how pastures can be managed without fire using intensive production systems. The program recognizes that burning is a traditional production practice in the country, but considers it backward and an "inadequate practice and an uncontrolled phenomenon, which has resulted in large forest fires in recent years" (PASF-II 2012:1). The intention to increase productivity also related to future visions shared by local authorities in Concepción and Roboré, who planned to subsidize mechanized land clearing in the coming years. An authority in Concepción explained:

We are intending to improve productivity in the future, so this is a vision of modernization... This is the vision for the livestock sector... [In agriculture] I also foresee an increase in the production capacity with a commercial logic. This process may be a bit slow in the indigenous communities but faster in the intercultural communities. (AUTCO02, Concepción, 27 August 2013)

\section{Scenario outcomes and uncertainty}

The baseline showed high wildfire occurrence, as well as high deforestation and livestock production (Fig. 5). Similar patterns were observed under the Hands-off scenario, with a rise in deforestation and livestock production compared to the baseline (Fig. 6). An increase in the "prolonged dry period" under the Hands-off scenario showed a significant decrease in agriculture production compared to the baseline.

Reduction in wildfire risk was higher in the Fire management scenario than in the Fire suppression scenario. This difference was observed even when assuming more prolonged dry periods, indicating that the wildfire system would be sensitive to improved fire management even under drier climatic conditions (Fig. 6). Most importantly, the Fire management scenario showed the least tradeoffs between wildfire risk reduction and production in the region.

\section{DISCUSSION}

\section{Understanding complex systems with FCM}

Although the FCMs developed by different actor types were distinct, the network structure analysis identified similar patterns that helped understand important aspects of the wildfire system in the Chiquitania. The relatively high number of transmitter variables in the FCMs implied that the system's function was perceived to be greatly influenced by a multiplicity of drivers, some of which were considered to be exogenous to the system, e.g., prolonged dry periods related to global phenomena, and some endogenous, i.e., fire users that were identified as important agents driving wildfires. Recognizing the importance of agency, actors could envisage different ways to deal with wildfire risk depending on their perceived role either as a user, manager, or policy maker in the system. This was an indication of their knowledge on this particular domain, and of existing interest to create conditions for change. Explicitly including actors as variables in the FCMs was helpful because it allowed participants to discuss specific entry points and agents that could catalyze change in the wildfire system.

Further analysis distinguished a set of few variables common to all FCMs, which played a key role in influencing system behavior and ultimately in reducing wildfire risk. This helped overcome somewhat the "noise" brought by the high number of transmitters (Gray et al. 2012) and narrow down the focus on particular components of the system that could be manipulated to evaluate possible outcomes. The interviews helped to contextualize the analysis and further understand the particularities of key drivers. This combination of steps helped answer the first research question guiding this study. The small number of highly connected and influential variables with many more variables exhibiting fewer connections was also observed by Özesmi (2006) in a meta-study of different FCMs representing peoples' perceptions of complex systems. Interestingly, the most central variables in the augmented FCM demonstrated low sensitivity to random variations in the relationships' weights. This is probably because their higher number of connections means that random uncertainties in various contributing connections tend to compensate each other, leading to moderate overall uncertainty in central variables.

Combining different FCMs allowed aggregation of diverse mental models and helped better specify the complexity of the wildfire system. No one's construction of reality is ever complete, so engaging groups of actors to develop FCMs and combining them helped coconstruct a more complete knowledge base building on similarities and differences in perception (Murungweni et al. 2011, Gray et al. 2012, Kontogianni et al. 2012). This process allowed 
Fig. 5. Bars show the baseline value of variables in the augmented fuzzy cognitive map (FCM) resulting from the inference produced based on current conditions. Baseline values could be interpreted as the influence/importance each variable has in the system from the combined perspective of the experts who participated in the FCM construction. The baseline is used as a reference to compare FCM inferences under different scenarios. Error bars represent uncertainty obtained by varying all the edge weights in the augmented FCM within $10 \%$ of their value.

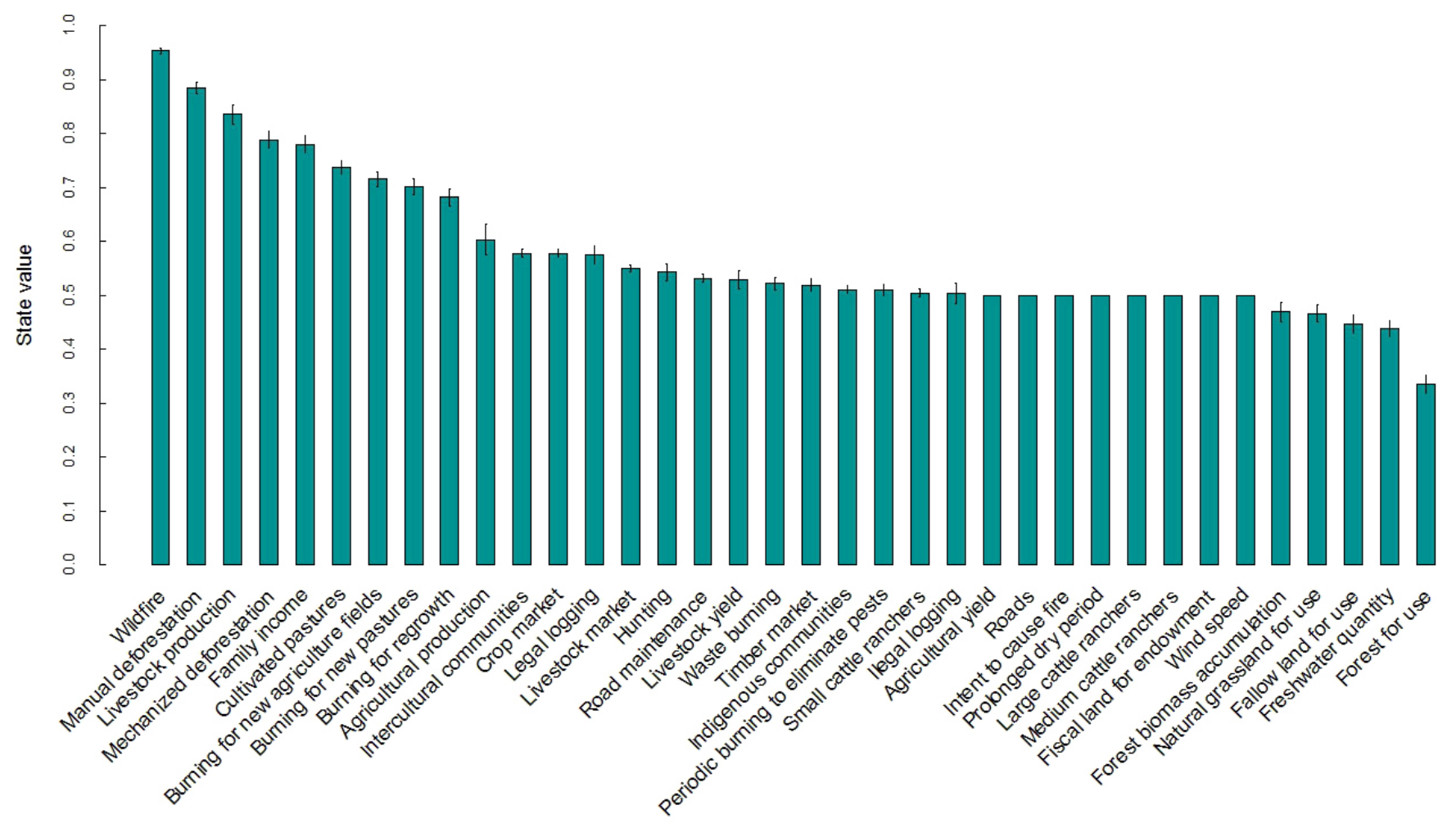

better characterization of the structural form and function of the system, which seemed to be more adaptable to local changes because of the higher level of connectivity and dependence among variables. According to scholars such as Bodin and Crona (2009) and Crona and Hubacek (2010) higher connectivity denotes change potential in the system to discourage undesirable states.

Future scenarios of wildfire risk and possible implications

The FCM method was successful in capturing feedbacks in the wildfire system. The inferences highlighted the need to account for climate change in strategies that anticipate future wildfire risk in the Chiquitania. This is particularly relevant considering future predictions of more extreme seasonality (Seiler 2009, Seiler et al. 2013). The FCM also generated insights into potential risks and trade-offs of these strategies, which can complement other studies focused on climate, fire, and land use change feedbacks in Amazonia (Nepstad et al. 2004, Aragão et al. 2008, Lee et al. 2011, Brando et al. 2014).

Where adaptation is not undertaken in response to a perceived risk, vulnerability will remain unchallenged and may indeed increase (Pelling 2011). This was observed in the Hands-off scenario outcome when addressing the second research question of this study. A passive attitude toward risk, combined with droughts and policies favoring expansion of the agricultural frontier, resulted in increased wildfire risk and actually a decrease in agriculture production compared to the baseline. Given that agriculture production is the main subsistence livelihood of indigenous communities in Concepción and Roboré, it could be argued that this actor type may become more vulnerable to wildfire risk in the context of future drier conditions.

When comparing the adaptation scenarios to assess their outcomes in light of our third research question, we realized that surprisingly wildfire risk in the Fire suppression scenario was higher than in the Fire management scenario. This implied that the reduction of ignition points in the Fire suppression scenario might not be enough to counteract the favorable conditions for wildfire created by other interacting variables in the system. Targeting only the fastest growing sector in the Chiquitania to reduce wildfire risk seemed to fail in delivering an effective systemic response because it missed other positive feedbacks. In the outlook of more severely dry seasons (Seiler 2009), this calls for measures to involve all fire users (not only a sector) to anticipate wildfire risk, yet keeping them actor-specific.

The fire risk strategies considered in the scenarios related to incremental adaptation. Incremental adaptation entails changes to the aims, rules, and practices within the prevailing political regime (Pelling 2011). Although both adaptation scenarios were 
Fig. 6. Scenario outcomes for selected variables in the augmented fuzzy cognitive map (FCM), including the effect of more prolonged dry periods for each scenario (noted as climate change, CC). Point symbols show state value of selected variables after scenario runs. Error bars represent the uncertainty in the model outputs obtained for each scenario by varying all the edge weights in the FCM within $10 \%$ of their value. The baseline and scenario outputs are separated by vertical lines to ease comparison.

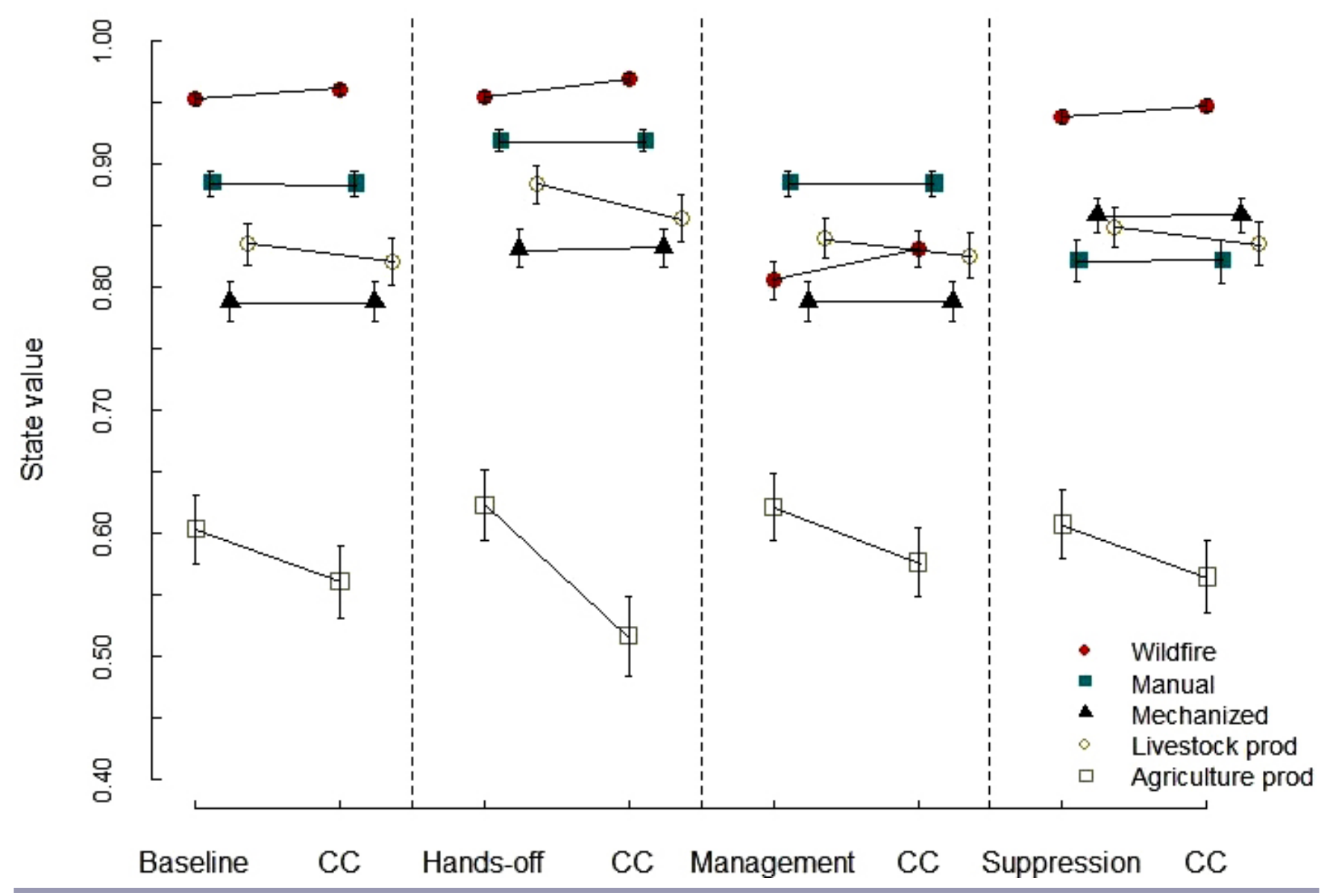

based on the collective adoption of best practices and technological improvements, the Fire management scenario related to a process initiated from within the system (inside-out), whereas the Fire suppression scenario was initiated from outside (outside-in). In the Fire management scenario, different actors endogenous to the system played a role in the uptake of improved burning practices expected to spread either vertically or horizontally. In the Fire suppression scenario, on the contrary, change was initiated by the state's interest to modernize "backward and dangerous" burning practices.

To some extent, the Fire suppression scenario conserved characteristics of a command-and-control approach because it aimed to partially constrain the variability in the system by eradicating the use of fire and avoiding exposure to wildfire. Holling and Meffe (1996) argued that by limiting variation and exposure, the system may lose its capacity to adapt and may become even more vulnerable to unanticipated disturbances. This was observed for example in Venezuela where suppression of traditional fire use in grassland-forest landscapes led to larger wildfires in recent years (Sletto and Rodriguez 2013). There are similar examples in other forest landscapes worldwide where suppression resulted in perverse outcomes (FAO 2011, Stephens et al. 2014). This may explain in part the higher wildfire risk observed in the Fire suppression scenario compared to the Fire management scenario. Regional experts also perceived that fire eradication could result in undesirable accumulation of biomass leading to larger wildfires. Some experts pondered prescribed burning as an additional strategy to manage wildfire risk in the Chiquitania.

Another important difference is that the Fire suppression scenario would require more investment in technological transfer and implementation than the Fire management scenario. Such investment may increase transition costs over time, enforcing path-dependence in the future (Gunderson and Holling 2002). Galaz (2014) warned that lock-in effects (in this case to technocentric approaches) could lead to irreversibility and undesirable outcomes. An undesirable outcome of the Fire suppression scenario would be increased vulnerability to large wildfires, but also a rise in deforestation. Deforestation could accelerate unless mechanized land clearing is accompanied by measures to prevent 
it. This is important in the context of eastern Bolivia where changes in land policy have triggered deforestation in the past (Pacheco 2006, Redo et al. 2011, Müller et al. 2014).

Although the Fire management scenario outcome showed the least trade-offs between wildfire risk reduction and production, there are limitations and risks to this approach. Reeder et al. (2009) argued that incremental adaptation can be dangerous and costly if major reforms are needed to deal with future risk. By improving burning practices, for instance, the Fire management approach does not limit fire use in properties that are increasingly expanding in size. According to Pinto and Vroomans (2007) the expansion of property size has largely contributed to accidental fires in recent years. In like manner, fire management strategies have not considered new fire users in intercultural communities that are spreading the use of fire into new forest frontiers of the Chiquitania. These fire users do not always have prior traditional knowledge about fire use, and therefore they represent an important risk factor. The Hands-off scenario did account for this trend and the outcomes were concerning.

Most likely different strategies considered in the scenarios will take place simultaneously in the Chiquitania. Indeed, combining different strategies may be necessary as activity at the niche level alone may not be sufficient to reduce wildfire risk at the system level. Pelling (2011) suggested a "nesting" of approaches, where different strategies can complement each other and changes at one scale facilitate changes at different scales. Nesting strategies to collectively anticipate wildfire risk would enable multilevel collaboration, which Ostrom (2008) introduced as a polycentric approach. Improved fire management, for example, may not be sufficient to prevent accidental fires in large properties, in which case mechanization and fire-free technology would be more appropriate. Likewise, mechanization would not be feasible in mountainous regions of the Chiquitania, where fire management would be a more suitable strategy. The spatio-temporal scales of impact would need to be carefully considered to implement a polycentric approach based on actor-specific strategies. The time and capacity to achieve a coordinated nesting of strategies that can have a system-level effect may indeed represent a "limit to adaptation" (Adger et al. 2009) to increased wildfire risk in the Chiquitania.

\section{Using FCM to support collaboration and decision making}

Özesmi and Özesmi (2004) recognized the potential of FCMs in strengthening the capacity of key actors to improve long-term management strategies. In this study, the coconstruction of FCMs proved to be an appropriate approach to engage different actors relevant to wildfire risk management. They contributed distinct knowledge, world views, and perceptions of fire. Although the development of the FCMs helped initiate discussion within the group of each actor type, a broader discussion that brings all actor types together is still unusual. Such dialogue would help different actors understand wildfire risk from different perspectives, which is a necessary step toward improving collaboration and nesting of strategies for a more systemic approach to wildfire risk.

In 2013 a Regional Fire Platform was launched in Santa Cruz to facilitate dialogue and coordination among all actors, regional to local, who can make a significant contribution to reduce wildfire risk in the region. The augmented FCM could potentially serve as an effective "boundary object" (Star and Griesemer 1989, Cash et al. 2002, 2003, White et al. 2010) to discuss scenario outcomes in this space and negotiate different perspectives. Star and Griesemer (1989:393) defined boundary objects as analytic concepts that "have different meanings in different social worlds but their structure is common enough to more than one world to make them recognizable, a means of translation." According to Cash et al. (2003) the use of boundary objects can contribute to the production of (i) more salient information by engaging the information users in the production, (ii) more credible information by engaging expertise, albeit maybe with conflicting views, and (iii) more legitimate information by providing greater access to the process for multiple perspectives and greater transparency. Based on this, we think that participatory models such as this FCM have the potential to serve as boundary objects and facilitate a more open discussion for "social learning" (HenlyShepard et al. 2015) and the production of useful information to improve management strategies.

So far the use of FCM in this study has helped address somewhat the mismatch between qualitative storylines, public concerns on increasingly large wildfires, and the model assumptions and parameters. The combination of interviews with the construction of FCMs based on what matters to participants helped capture relevant trends and possible future trajectories to build the scenarios. Because participants would be familiar with the model and to certain extent have ownership of the results, we believe the FCM has the potential to be used as a decision-support tool for wildfire management in the Chiquitania. The timing of these results is also appropriate because the government of Santa Cruz is developing a new 10 -year program to manage wildfire risk in the region. The use of the FCM model to support decisionmaking processes in the Chiquitania remains to be tested as we go back to the region to share the results and facilitate exchange between the participants that helped in its development.

\section{CONCLUSION}

The FCM model was successful in identifying key forcing variables driving the wildfire system in the Chiquitania and generating possible "what if" scenarios based on perceptions of key actors relevant to wildfire risk management in the region. The semistructured interviews contributed to capture some of the "whys" to inform scenario design and ground the discussion of the outcomes. Given the uncertainty around variables and feedbacks in the wildfire system, the FCM model was used to assess different possible scenarios rather than produce an accurate prediction of the future. The uncertainty analysis helped increase robustness of the outcomes generated with the FCM model.

A passive attitude toward increased wildfire risk in the context of intensifying trends led to higher vulnerability in the future. Under extremely dry conditions, this seemed to affect particularly the agricultural production, which is the main livelihood of local communities in the region. Unexpectedly, the Fire management scenario showed lower wildfire risk than the Fire suppression scenario, even under drier climatic conditions. The reduction of ignition points under the Fire suppression scenario seemed insufficient to balance the reinforcing feedbacks among other variables in the system.

Most likely, strategies will need to be nested for a more systemic approach to anticipate and better manage wildfire risk in the future. The FCM model has the potential to support this process 
by informing management decisions and facilitating discussion between different actor types. This is particularly important given the interest of the government in Santa Cruz to improve wildfire risk management with a new program and the recently launched Regional Fire Platform.

The findings of this study also provide specific hypotheses that could be tested in further research to include more quantitative data and explicit spatial and temporal dimensions. As wildfire becomes a growing global concern with climate change, the findings and the approach used in this study are relevant contributions to advance wildfire risk adaptation in other dynamic frontier landscapes around the world.

Responses to this article can be read online at: http://www.ecologyandsociety.org/issues/responses. $\mathrm{php} / 8599$

\section{Acknowledgments:}

This study was conducted with support from the Fundacion Amigos de la Naturaleza, Fundación para la Conservación del Bosque Chiquitano, and the Stockholm Environment Institute. It was also supported by the Municipal Governments of Concepción and Roboré. Special thanks to U. Özesmi, M. Van Wijk, and K. Kok who provided insights and critical feedback on the FCM method. We are also grateful to the two anonymous reviewers who helped improve the manuscript. Y.M. is supported by the Jackson Foundation and a European Research Council Advanced Investigator Award. T.D. was supported by the Osmaston Scholarship during the fieldwork for this study. E. B. is supported by the Economic and Social Research Council and Natural Environment Research Council. The authors have no conflict of interest to declare.

\section{LITERATURE CITED}

Adger, W. N., S. Dessai, M. Goulden, M. Hulme, I. Lorenzoni, D. R. Nelson, L. O. Naess, J. Wolf, and A. Wreford. 2009. Are there social limits to adaptation to climate change? Climatic Change 93:335-354. http://dx.doi.org/10.1007/s10584-008-9520$\underline{z}$

Alencar, A. C., L. A. Solórzano, and D. C. Nepstad. 2004. Modeling forest understory fires in an Eastern Amazonian landscape. Ecological Applications 14:139-149. http://dx.doi. org/10.1890/01-6029

Anderson, L. O., L. E. O. C. Aragão, M. Gloor, E. Arai, M. Adami, S. S. Saatchi, Y. Malhi, Y. E. Shimabukuro, J. Barlow, E. Berenger, and V. Duarte. 2015. Disentangling the contribution of multiple land covers for fire-mediated carbon emission in Amazonia during the 2010 drought. Global Biogeochemical Cycles 29:1739-1753. http://dx.doi.org/10.1002/2014GB005008

Aragão, L. E. O. C., Y. Malhi, N. Barbier, A. Lima, Y. Shimabukuro, L. Anderson, and S. Saatchi. 2008. Interactions between rainfall, deforestation and fires during recent years in the Brazilian Amazonia. Philosophical Transactions of the Royal Society B 363:1779-1785. http://dx.doi.org/10.1098/rstb.2007.0026
Barlow, J., L. Parry, T. A. Gardner, J. Ferreira, L. E. O. C. Aragão, R. Carmenta, E. Berenguer, I. C. G. Vieira, C. Souza, and M. A. Cochrane. 2012. The critical importance of considering fire in REDD+ programs. Biological Conservation 154:1-8. http://dx. doi.org/10.1016/j.biocon.2012.03.034

Bodin, Ö., and B. I. Crona. 2009. The role of social networks in natural resource governance: What relational patterns make a difference? Global Environmental Change 19:366-374. http://dx. doi.org/10.1016/j.gloenvcha.2009.05.002

Boyd, E. 2008. Navigating Amazonia under uncertainty: past, present and future environmental governance. Philosophical Transactions of the Royal Society B 363:1911-1916. http://dx.doi. org/10.1098/rstb.2007.0023

Boyd, E., B. Nykvist, S. Borgström, and I. A. Stacewicz. 2015. Anticipatory governance for social-ecological resilience. Ambio 44:149-161. http://dx.doi.org/10.1007/s13280-014-0604-x

Brando, P. M., J. K. Balch, D. C. Nepstad, D. C. Morton, F. E. Putz, M. T. Coe, D. Silvério, M. N. Macedo, E. A. Davidson, C. C. Nóbregal, A. Alencar, and B. S. Soares-Filho. 2014. Abrupt increases in Amazonian tree mortality due to drought-fire interactions. Proceedings of the National Academy of Sciences of the United States of America 111(17):6347-6352. http://dx.doi. org/10.1073/pnas.1305499111

Cash, D., W. C. Clark, F. Alcock, N. M. Dickson, N. Eckley, and J. Jäger. 2002. Salience, credibility, legitimacy and boundaries: linking research, assessment and decision making. Faculty Research Working Paper Series. Harvard University, Cambridge, Massachusetts, USA. http://dx.doi.org/10.2139/ssrn.372280

Cash, D. W., W. C. Clark, F. Alcock, N. M. Dickson, N. Eckley, D. H. Guston, J. Jäger, and R. Mitchell. 2003. Knowledge systems for sustainable development. Proceedings of the National Academy of Sciences of the United States of America 100 (14):8086-8091. http://dx.doi.org/10.1073/pnas. 1231332100

Chapin, F. S., G. P. Kofinas, and C. Folke. 2009. Principles of ecosystem stewardship. Springer Science+Business Media, New York, New York, USA.

Christensen, J. H., B. Hewitson, A. Busuioc, A. Chen, X. Gao, I. Held, R. Jones, R. K. Kolli, W. T. Kwon, R. Laprise, V. Magaña Rueda, L. Mearns, C. G. Menéndez, J. Räisänen, A. Rinke, A. Sarr, and P. Whetton. 2007. Regional climate projections. Chapter 11 in S. Solomon, D. Qin, M. Manning, Z. Chen, M. Marquis, K. B. Averyt, M. Tignor, and H. L. Miller, editors. Climate change 2007: the physical science basis. Cambridge University Press, Cambridge, UK.

Cochrane, M. A., and W. F. Laurence. 2008. Synergisms among fire, land use, and climate change in the Amazon. Ambio 37:522-527. http://dx.doi.org/10.1579/0044-7447-37.7.522

Cox, P. M., R. A. Betts, M. Collins, P. P. Harris, C. Huntingford, and C. D. Jones. 2004. Amazonian forest dieback under climatecarbon cycle projections for the 21 st century. Theoretical and Applied Climatology 78:137-156. http://dx.doi.org/10.1007/ s00704-004-0049-4

Crona, B., and K. Hubacek. 2010. The right connections: How do social networks lubricate the machinery of natural resource 
governance? Ecology and Society 15(4):18. [online] URL: http:// www.ecologyandsociety.org/vol15/iss4/art18/

Davidson, E. A., A. C. Araújo, P. Artaxo, J. K. Balch, I. F. Brown, M. M. C. Bustamante, M. T. Coe, R. S. DeFries, M. Keller, M. Longo, J. W. Munger, W. Schroeder, B. S. Soares-Filho, C. M. Souza, and S. C. Wofsy. 2012. The Amazon basin in transition. Nature 481:321-328. http://dx.doi.org/10.1038/nature10717

Dexter, N., D. S. L. Ramsey, C. MacGregor, and D. Lindenmayer. 2012. Predicting ecosystem wide impacts of wallaby management using a fuzzy cognitive map. Ecosystems 15:1363-1379. http://dx. doi.org/10.1007/s10021-012-9590-7

Diestel, R. 2005. Graph theory. Third edition. Springer-Verlag Heidelberg, New York, New York, USA.

Field, C. B., V. Barros, T. F. Stocker, D. Qin, D. J. Dokken, K. L. Ebi, M. D. Mastrandrea, K. J. Mach, G. K. Plattner, S. K. Allen, M. Tignor, and P. M. Midgley. 2012. Managing the risks of extreme events and disasters to advance climate change adaptation. Special Report of Working Groups I and II of the Intergovernmental Panel on Climate Change. Cambridge University Press, Cambridge, UK. http://dx.doi.org/10.1017/cbo9781139177245

Food and Agriculture Organization (FAO). 2011. Findings and implications from a coarse-scale global assessment of recent selected mega-fires. 5th International Wildland Fire Conference. 9-13 May. FAO, Sun City, South Africa.

Fundación Tierra. 2015. Cumbre Agropecuaria: Sembrando Bolivia. Apuntes críticos para la agenda agropecuaria. Fundación Tierra, La Paz, Bolivia.

Galaz, V. 2014. Global environmental governance, technology and politics: the Anthropocene gap. Edward Elgar, Cheltenham, UK. http://dx.doi.org/10.4337/9781781955550

Giordano, R., G. Passarella, V. F. Uricchio, and M. Vurro. 2005. Fuzzy cognitive maps for issue identification in a water resources conflict resolution system. Physics and Chemistry of the Earth 30:463-469. http://dx.doi.org/10.1016/j.pce.2005.06.012

Government of Bolivia. 2013. Law N337. Ley de Apoyo a la Producción de alimentos y restitucion de bosques. La Asamblea Legislativa Plurinacional. Government of Bolivia, La Paz, Bolivia. [online] URL: http://www.lexivox.org/norms/BO-LN337.xhtml

Government of Bolivia. 2015. Law N650. Agenda Patriótica del Bicenternario 2025. Ministerio de Autonomías. Government of Bolivia, La Paz, Bolivia. [online] URL: http://www.lexivox.org/ norms/BO-L-N650.xhtml

Gray, S., A. Chan, D. Clark, and R. Jordan. 2012. Modeling the integration of stakeholder knowledge in social-ecological decision-making: benefits and limitations to knowledge diversity. Ecological Modelling 229:88-96. http://dx.doi.org/10.1016/j. ecolmodel.2011.09.011

Gray, S. A., S. Gray, L. J. Cox, and S. Henly-Shepard. 2013. Mental modeler: a fuzzy-logic cognitive mapping modeling tool for adaptive environmental management. System Sciences (HICSS), 46th Hawaii International Conference on System Sciences. http://dx.doi.org/10.1109/HICSS.2013.399
Gunderson, L. H., and C. S. Holling. 2002. Panarchy: understanding transformations in human and natural systems. Island Press, Washington, D.C., USA.

Hardy, C. C. 2005. Wildland fire hazard and risk: problems, definitions, and context. Forest Ecology and Management 211 (1-2):73-82. http://dx.doi.org/10.1016/j.foreco.2005.01.029

Henly-Shepard, S., S. A. Gray, and L. J. Cox. 2015. The use of participatory modeling to promote social learning and facilitate community disaster planning. Environmental Science \& Policy 45:109-122. http://dx.doi.org/10.1016/j.envsci.2014.10.004

Hobbs, B. F., S. A. Ludsin, R. L. Knight, P. Ryan, J. Biberhofer, and J. J. H. Ciborowski. 2002. Fuzzy cognitive mapping as a tool to define management objectives for complex systems. Ecological Applications 12:1548-1565. http://dx.doi.org/10.1890/1051-0761 (2002)012[1548:FCMAAT]2.0.CO;2

Holling, C. S., and G. K. Meffe. 1996. Command and control and the pathology of natural resource management. Conservation Biology 10:328-337. http://dx.doi.org/10.1046/j.1523-1739.1996.10020328. $\underline{\mathrm{X}}$

Ibarnegaray, V., C. Pinto, and A. Rodriguez-Montellano. 2014. El manejo comunitario del fuego: un enfoque participativo para la gestión de incendios forestales en Bolivia. FAN Policy Brief [online] URL: http://www.fan-bo.org/wp-content/files/policybriefMCF. pdf

Intergovernmental Panel on Climate Change (IPCC). 2001. Climate change 2001: impacts, adaptation, and vulnerability. Contribution of Working Group II to the Third Assessment Report of the Intergovernmental Panel on Climate Change. J. J. McCarthy, O. F. Canziani, N. A. Leary, D. J. Dokken, and K. S. White, editors. Cambridge University Press, Cambridge, UK.

International Model Forest Network (IMFN). 2011. A global approach to ecosystem sustainability. IMFN, Ottawa, Ontario, Canada.

International Model Forest Network (IMFN). 2013. Chiquitano model forest. IMFN, Ottawa, Ontario, Canada. [online] URL: http://imfn.net/chiquitano-model-forest

Justiniano, H., R. Vides, J. Flores, and L. Faldín. 2014. La importancia de las organizaciones civiles en el financiamiento de un Bosque Modelo: La experiencia del Bosque Modelo Chiquitano. Serie "Experiencias de Bosques Modelo." Red Iberoamericana de Bosques Modelo (RIABM), La Paz, Bolivia.

Killeen, T. J., A. Guerra, M. Calzada, L. Correa, V. Calderon, L. Soria, B. Quezada, and M. K. Steininger. 2008. Total historical land-use change in eastern Bolivia: who, where, when, and how much? Ecology and Society 13(1):36. [online] URL: http://www. ecologyandsociety.org/vol13/iss1/art36/

Killeen, T., A. Jardim, F. Manami, and N. Rojas. 1998. Diversity, composition and structure of a tropical semideciduous forest in the Chiquitanía region of Santa Cruz, Bolivia. Journal of Tropical Ecology 14:803-827. http://dx.doi.org/10.1017/S0266467498000583

Kok, K. 2009. The potential of fuzzy cognitive maps for semiquantitative scenario development, with an example from Brazil. Global Environmental Change 19:122-133. http://dx.doi. org/10.1016/j.gloenvcha.2008.08.003 
Kontogianni, A. D., E. I. Papageorgiou, and C. Tourkolias. 2012. How do you perceive environmental change? Fuzzy cognitive mapping informing stakeholder analysis for environmental policy making and non-market valuation. Applied Soft Computing 12:3725-3735. http://dx.doi.org/10.1016/j.asoc.2012.05.003

Kosko, B. 1986. Fuzzy cognitive maps. International Journal of Man-Machine Studies 24(1):65-75. http://dx.doi.org/10.1016/ $\underline{\text { s0020-7373(86)80040-2 }}$

Kosko, B. 1988. Hidden patterns in combined and adaptive knowledge networks. International Journal of Approximate Reasoning 2:377-393. http://dx.doi.org/10.1016/0888-613X(88) 90111-9

Kosko, B. 1992. Neural networks and fuzzy systems: a dynamical systems approach to machine intelligence. Prentice-Hall, Englewood Cliffs, New Jersey, USA.

Leach, M., I. Scoones, and A. Stirling. 2007. Pathways to sustainability: an overview of the STEPS Centre approach. STEPS Centre, Brighton, UK.

Leach, M., I. Scoones, and A. Stirling. 2010. Dynamic sustainabilities. Technology, environment, socialjustice. Earthscan, London, UK.

Lee, J., B. R. Lintner, C. K. Boyce, and P. J. Lawrence. 2011. Land use change exacerbates tropical South American drought by sea surface temperature variability. Geophysical Research Letters 38 (19). doi: 10.1029/2011GL049066 http://dx.doi.org/10.1029/201$\underline{1 \mathrm{GL} 049066}$

Lewis, S. L., P. M. Brando, O. L. Phillips, G. M. F. van der Heijden, and D. Nepstad. 2011. The 2010 Amazon drought. Science 331 (6017):554. http://dx.doi.org/10.1126/science.1200807

MacDonald, N. 1983. Trees and networks in biological models. John Wiley \& Sons, New York, New York, USA.

Marengo, J. A., J. Tomasella, L. M. Alves, W. R. Soares, and D. A. Rodriguez. 2011. The drought of 2010 in the context of historical droughts in the Amazon region. Geophysical Research Letters 38(12). http://dx.doi.org/10.1029/2011GL047436

McDaniel, J., D. Kennard, and A. Fuentes. 2005. Smokey the tapir: traditional fire knowledge and fire prevention campaigns in lowland Bolivia. Society and Natural Resources 18:921-931. http://dx.doi.org/10.1080/08941920500248921

Mendoza, G. A., and R. Prabhu. 2006. Participatory modelling and analysis for sustainable forest management: overview of soft system dynamics models and applications. Forest Policy and Economics 9:179-196. http://dx.doi.org/10.1016/j.forpol.2005.06.006

Murungweni, C., M. T. Van Wijk, J. A. Andersson, E. M. A. Smaling, and K. E. Giller. 2011. Application of fuzzy cognitive mapping in livelihood vulnerability analysis. Ecology and Society 16(4):8. http://dx.doi.org/10.5751/es-04393-160408

Müller, R., D. M. Larrea-Alcázar, S. Cuéllar, and S. Espinoza. 2014. Causas directas de la deforestación reciente (2000-2010) y modelado de dos escenarios futuros en las tierras bajas de Bolivia. Ecología en Bolivia 49:20-34.

Nepstad, D., P. Lefebvre, U. L. da Silva, J. Tomasella, P. Schlesinger, L. Solórzano, P. Moutinho, D. Ray, and J. G. Benito. 2004. Amazon drought and its implications for forest flammability and tree growth: a basin-wide analysis. Global Change Biology 10:704-717. http://dx.doi.org/10.1111/ j.1529-8817.2003.00772.x

Newman, M. 2010. Networks: an introduction. Oxford University Press, Oxford, UK. http://dx.doi.org/10.1093/acprof: oso/9780199206650.001.0001

Nuttall, M. 2010. Anticipation, climate change, and movement in Greenland. Les Inuit et le changement climatique/The Inuit and Climate Change 34:21-37. http://dx.doi.org/10.7202/045402ar

O'Brien, K., and J. Barnett. 2013. Global environmental change and human security. Annual Review of Environment and Resources 38:373-391. http://dx.doi.org/10.1146/annurev-environ-032112-100655

O’Brien, K., L. Sygna, R. Leichenko, W. N. Adger, J. Barnett, T. Mitchell, L. Schipper, T. Tanner, C. Vogel, and C. Mortreux. 2008. Disaster risk reduction, climate change adaptation and human security. Report prepared for the Royal Norwegian Ministry of Foreign Affairs by the Global Environmental Change and Human Security (GECHS) Project, Oslo, Norway.

Ostrom, E. 2008. Polycentric systems as one approach for solving collective-action problems. School of Public \& Environmental Affairs Research Paper, Indiana University, Bloomington, Indiana, USA. http://dx.doi.org/10.2139/ssrn.1304697

Özesmi, U. 2006. Perceptions of complex systems are governed by power laws. Erciyes University, Kayseri, Turkey. [online] URL: http://arxiv.org/abs/q-bio/0601033v1

Özesmi, U., and S. Özesmi. 2003. A participatory approach to ecosystem conservation: fuzzy cognitive maps and stakeholder group analysis in Uluabat Lake, Turkey. Environmental Management 31:518-531. http://dx.doi.org/10.1007/s00267-002-2841-1

Özesmi, U., and S. L. Özesmi. 2004. Ecological models based on people's knowledge: a multi-step fuzzy cognitive mapping approach. Ecological Modelling 176:43-64. http://dx.doi. org/10.1016/j.ecolmodel.2003.10.027

Pacheco, P. 2006. Agricultural expansion and deforestation in lowland Bolivia: the import substitution versus the structural adjustment model. Land Use Policy 23(3):205-225. http://dx.doi. org/10.1016/j.landusepol.2004.09.004

Pacheco, P., and B. Mertens. 2004. Land use change and agricultural development in Santa Cruz, Bolivia. Bois et Forêts des Tropiques 280:30-40.

Papageorgiou, E. I. 2011. Review study of fuzzy cognitive maps and their applications during the last decade. IEEE International Conference on Fuzzy Systems (FUZZ), 27-30 June, Taipei, Taiwan. http://dx.doi.org/10.1109/fuzzy.2011.6007670

PASF-II. 2012. Programa "Amazonia sin Fuego FASE II: Gestión 2012-13" - PASF-II. Government of Bolivia, La Paz, Bolivia, and Cooperazione Italiana allo Sviluppo, Ministero degli Affari Esteri e della Cooperazione Internazionale, Rome, Italy. [online] URL: http://www.cooperazioneallosviluppo.esteri.it/pdgcs/Documentazione/ BandiAvvisi/2012-07-04_Amazonia_programma.pdf

Patt, A. G., and D. Schröter. 2008. Perceptions of climate risk in Mozambique: implications for the success of adaptation strategies. Global Environmental Change 18:458-467. http://dx. doi.org/10.1016/j.gloenvcha.2008.04.002 
Pelling, M. 2011. Adaptation to climate change: from resilience to transformation. Routledge, London, UK.

Peredo-Videa, B. 2008. Climate change, energy and biodiversity conservation in Bolivia: roles, dynamics and policy responses. Policy Matters 16:163-189.

Peredo-Videa, B. 2011. Forest fires, climate change and well-being in Bolivia: elements for discussion and policy responses. Oxfam, La Paz, Bolivia.

Peterson, G. D., G. S. Cumming, and S. R. Carpenter. 2003. Scenario planning: a tool for conservation in an uncertain world. Conservation Biology 17:358-366. http://dx.doi.org/10.1046/ j.1523-1739.2003.01491.x

Pinto, C., and V. Vroomans. 2007. Chaqueos e Incendios Forestales en Bolivia. Instituto Boliviano de Investigación Forestal, Santa Cruz, Bolivia.

Poli, R. 2010. The many aspects of anticipation. Foresight 12:7-17. http://dx.doi.org/10.1108/14636681011049839

Quay, R. 2010. Anticipatory governance: a tool for climate change adaptation. Journal of the American Planning Association 76:496-511. http://dx.doi.org/10.1080/01944363.2010.508428

Rajaram, T., and A. Das. 2010. Modeling of interactions among sustainability components of an agro-ecosystem using local knowledge through cognitive mapping and fuzzy inference system. Expert Systems with Applications 37:1734-1744. http://dx. doi.org/10.1016/j.eswa.2009.07.035

Reckien, D. 2014. Weather extremes and street life in India implications of fuzzy cognitive mapping as a new tool for semiquantitative impact assessment and ranking of adaptation measures. Global Environmental Change 26:1-13. http://dx.doi. org/10.1016/j.gloenvcha.2014.03.005

Redo, D., A. C. Millington, and D. Hindery. 2011. Deforestation dynamics and policy changes in Bolivia's post-neoliberal era. Land Use Policy 28:227-241. http://dx.doi.org/10.1016/j. landusepol.2010.06.004

Reeder, T., J. Wicks, L. Lovell, and O. Tarrant. 2009. Protecting London from tidal flooding: limits to engineering adaptation. Pages 54-63 in W. N Adger, I. Lorenzoni, and K. L. O'Brien, editors. Adapting to climate change: thresholds, values, governance. Cambridge University Press, Cambridge, UK. http://dx.doi. org/10.1017/cbo9780511596667.005

RIABM (Ibero-American Model Forest Network). 2015. About us. RIABM, Cartago, Costa Rica. [online] URL: http://www. bosquesmodelo.net/en/quienes-somos/

Rodriguez-Montellano, A. M. 2014. Incendios y quemas en Bolivia, análisis histórico desde 2000 a 2013. Editorial Fundación Amigos de la Naturaleza (FAN), Santa Cruz, Bolivia.

Saatchi, S., S. Asefi-Najafabady, Y. Malhi, L. E. O. C. Aragão, L. O. Anderson, R. B. Myneni, and R. Nemani. 2013. Persistent effects of a severe drought on Amazonian forest canopy. Proceedings of the National Academy of Sciences of the United States of America 110:565-570. http://dx.doi.org/10.1073/ pnas. 1204651110
Salski, A. 1992. Fuzzy knowledge-based models in ecological research. Ecological Modelling 63:103-112. http://dx.doi. org/10.1016/0304-3800(92)90064-L

Schipper, L., and M. Pelling. 2006. Disaster risk, climate change and international development: scope for, and challenges to, integration. Disasters 30:19-38. http://dx.doi.org/10.1111/ j.1467-9523.2006.00304.X

Seiler, C. 2009. Implementation and validation of a regional climate model for Bolivia. Editorial Fundación Amigos de la Naturaleza, Santa Cruz, Bolivia.

Seiler, C., R. W. A. Hutjes, and P. Kabat. 2013. Likely ranges of climate change in Bolivia. American Meteorology Society 52:1303-1317. http://dx.doi.org/10.1175/jamc-d-12-0224.1

Sletto, B., and J. Rodriguez. 2013. Burning, fire prevention and landscape productions among the Pemon, Gran Sabana, Venezuela: toward an intercultural approach to wildland fire management in Neotropical Savannas. Journal of Environmental Management 115:155-166. http://dx.doi.org/10.1016/j. jenvman.2012.10.041

Smit, B., and J. Wandel. 2006. Adaptation, adaptive capacity and vulnerability. Global Environmental Change 16:282-292. http://dx. doi.org/10.1016/j.gloenvcha.2006.03.008

Soler, L. S., K. Kok, G. Camara, and A. Veldkamp. 2012. Using fuzzy cognitive maps to describe current system dynamics and develop land cover scenarios: a case study in the Brazilian Amazon. Journal of Land Use Science 7:149-175. http://dx.doi. org/10.1080/1747423X.2010.542495

Star, S. L., and J. R. Griesemer. 1989. Institutional ecology, 'translations' and boundary objects: amateurs and professionals in Berkeley's Museum of Vertebrate Zoology, 1907-39. Social Studies of Science 19:387-420. http://dx.doi.org/10.1177/030631$\underline{289019003001}$

Stephens, S. L., N. Burrows, A. Buyantuyev, R. W. Gray, R. E. Keane, R. Kubian, S. Liu, F. Seijo, L. Shu, K. G. Tolhurst, and J. W. van Wagtendonk. 2014. Temperate and boreal forest megafires: characteristics and challenges. Frontiers in Ecology and the Environment 12:115-122. http://dx.doi.org/10.1890/120332

Unidad Técnica Nacional de Información de la Tierra (UTNIT). 2010. Cobertura de uso actual de la tierra 2010. [online] URL: http://cdrnbolivia.org/geografia-fisica-nacional.htm

Vides, R., S. Reichle, and F. Padilla. 2007. Planificación ecorregional del Bosque Seco Chiquitano. Fundación para la Conservación del Bosque Chiquitano (FCBC), Santa Cruz, Bolivia.

Wasserman, S., and K. Faust. 1994. Social network analysis: methods and applications. Cambridge University Press, Cambridge, UK. http://dx.doi.org/10.1017/cbo9780511815478

White, D. D., A. Wutich, K. L. Larson, P. Gober, T. Lant, and C. Senneville. 2010. Credibility, salience, and legitimacy of boundary objects: water managers' assessment of a simulation model in an immersive decision theater. Science and Public Policy 37(3): 219-232. http://dx.doi.org/10.3152/030234210x497726 
Ecology and Society 21(4): 18 http://www.ecologyandsociety.org/vol21/iss4/art18/

Williams, J. W., S. T. Jackson, and J. E. Kutzbach. 2007. Projected distributions of novel and disappearing climates by 2100 AD. Proceedings of the National Academy of Sciences of the United States of America 104(4):5738-5742. http://dx.doi.org/10.1073/ pnas.0606292104 


\section{Appendix 1. Selection criteria.}

Table A1.1. Criteria to select communities for semistructured interviews.

1. Representativeness of the Chiquitano ethnic group

2. Consolidated and recognized by the State

3. Road accessibility during the fieldwork period

4. Subsistence agriculture as the main livelihood, complemented with other activities such as cash crop agriculture, cattle ranching, and forestry

Table A1.2. Criteria to select expert participants for the focus groups.

1. Knowledge of the local social and ecological dynamics of wildfire

2. Expertise with fire use or management

3. Knowledge of agricultural and land management systems

4. More than ten years working on or living in the study sites 
Appendix 2. Photos showing examples of Fuzzy Cognitive Map (FCM) construction by different focus groups.

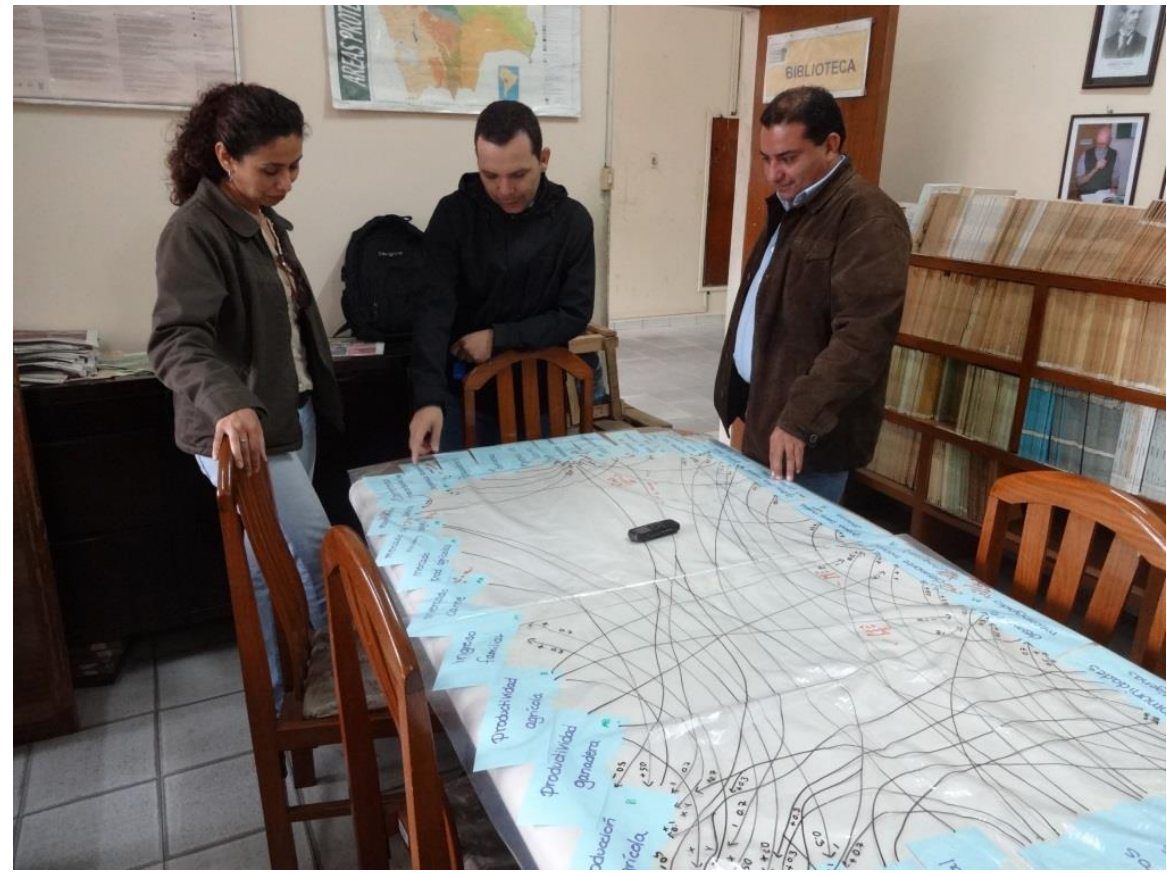

FCM construction by the group of experts from the regional government, research and nongovernmental organisations working on wildfire risk, Santa Cruz.

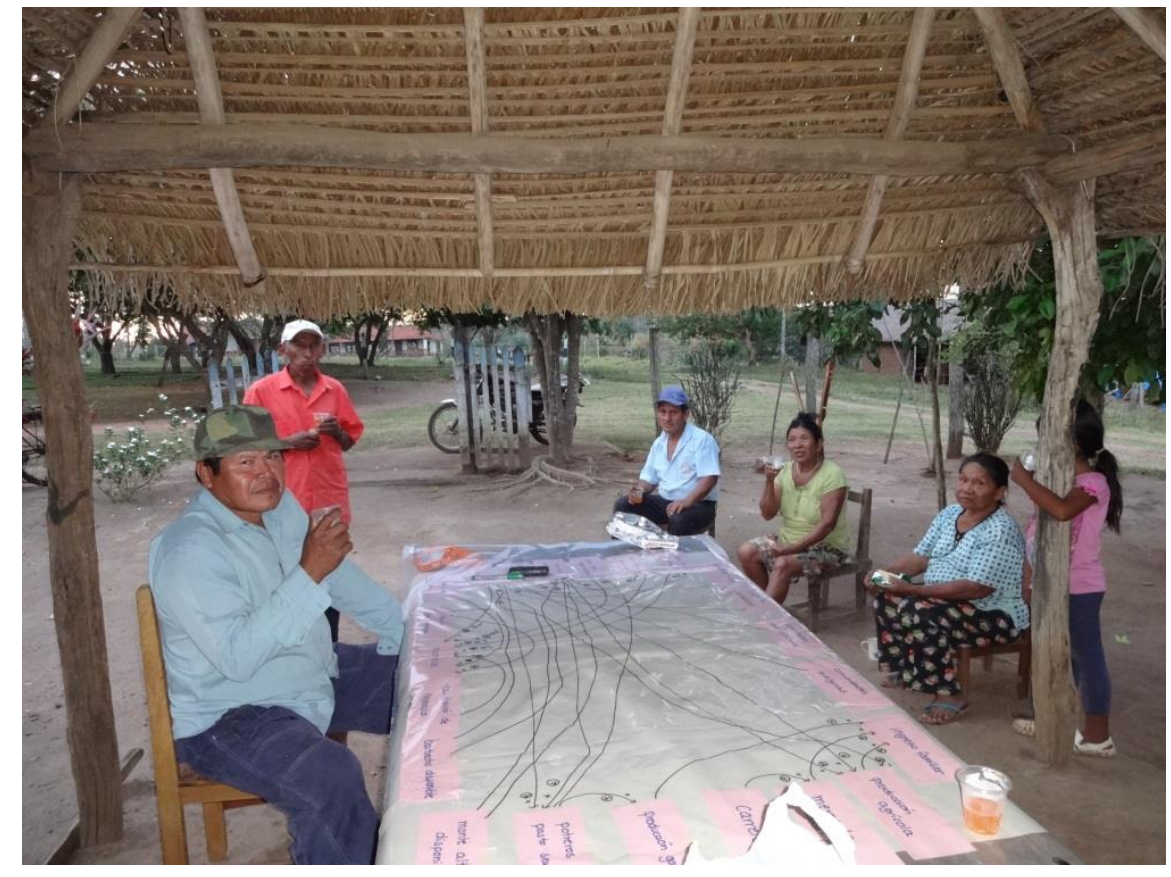

FCM construction with the group of experts from local indigenous communities, Concepción. 
Appendix 3. Adjacency matrix of the augmented FCM.

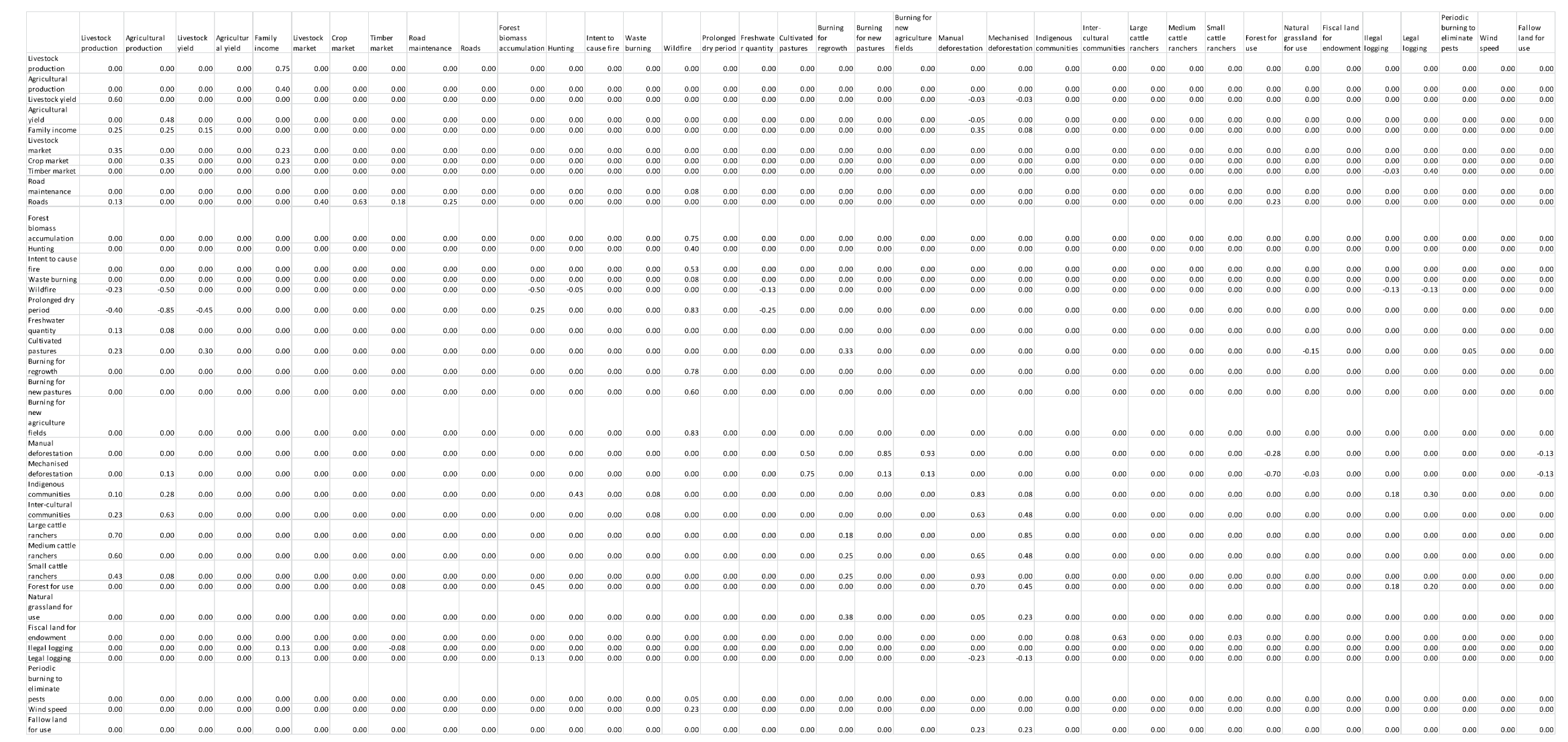


Appendix 4. Method to generate FCM inferences.

Fuzzy cognitive maps (FCMs) use fuzzy-graph structures to represent causal relationships (i.e. directed connections) among variables (i.e. concepts) as perceived by people. The use of cognitive maps to represent people's perception of systems has its origins in politics (Axelrod 1976). Kosko (1986) modified and extended their use by applying fuzzy causal functions with real numbers in [-1,1] to the edges. The weighted edge $w_{\mathrm{ij}}$ from causal concept $C_{\mathrm{i}}$ to concept $C_{\mathrm{j}}$ measures how much $C_{\mathrm{i}}$ at the originating end causes or influences $C_{\mathrm{j}}$ at the other end (Kosko 1992). The sign indicates if the relationship between $C_{\mathrm{j}}$ and $C_{\mathrm{i}}$ is positive or negative. In most FCMs, weights $w_{\mathrm{ij}} \in[-1,1]$ are specified by experts based on observation, empirical data or expert opinion.

For the FCM inference, a vector of initial state of variables $C$ was first multiplied with the adjacency matrix of the augmented FCM, which contained all of the weights $w$ of the connections among the variables. The state values of variables range in [0,1]. For the baseline run, the initial state vector assumed a value of 1 for each variable in the vector. Second, each element of the vector resulting from the multiplication was subjected to a logistic function to keep the values into the interval $[0,1]$ as in Eq. A4.1. Third, the new transformed vector was multiplied again with the adjacency matrix and the elements were subjected again to transformation. This process was repeated until the system converged. The FCM inferences could also implode, explode, show cyclic stabilization, or set into a chaotic attractor (Özesmi and Özesmi 2004, Kok 2009). According to Kok (2009) the pattern can usually be determined after 20 to 30 iterations. Our values stabilized in 21 iterations.

\section{Eq. A4.1.}

$$
C_{i}^{(k+1)}=f_{i}\left(C_{i}^{(k)}+\sum_{\substack{j \neq i \\ j=1}}^{N} C_{j}^{(k)} e_{j i}\right)
$$

where $\mathrm{f}_{\mathrm{i}}()$ is an activation function for variable $\mathrm{C}_{\mathrm{i}}$ using a logistic function to transform the results into the interval $[0,1] . \mathrm{C}_{\mathrm{i}}^{\left({ }^{(k+1)}\right)}$ is the value of variable $\mathrm{C}_{\mathrm{i}}$ at iteration step $k+1, \mathrm{C}_{\mathrm{i}}{ }^{(\mathrm{k})}$ is the value of concept $\mathrm{C}_{\mathrm{i}}$ at step $k, \mathrm{C}_{\mathrm{j}}^{(\mathrm{k})}$ is the value of concept $\mathrm{C}_{\mathrm{j}}$ at step $k$, and $\mathrm{e}_{\mathrm{ji}}$ is the weight of the causal relationship between variable $C_{j}$ and variable $C_{i}$. Transformation using a logistic function was applied to better understand and represent activation levels of variables and comparison among variables (Özesmi and Özesmi 2004). 


\section{Literature cited}

Axelrod, R. 1976. Structure of Decision: The Cognitive Maps of Political Elites. Princeton University Press, Princeton, NJ, US.

Kok, K. 2009. The potential of Fuzzy Cognitive Maps for semi-quantitative scenario development, with an example from Brazil. Global Environmental Change 19:122-133.

Kosko, B. 1986. Fuzzy cognitive maps. International Journal of Man-Machine Studies 1:65-75.

Kosko, B. 1992. Neural Networks and Fuzzy Systems: A Dynamical Systems Approach to Machine Intelligence. Prentice-Hall, Englewood Cliffs, NJ, US.

Özesmi, U., S.L. Özesmi. 2004. Ecological models based on people's knowledge: a multi-step fuzzy cognitive mapping approach. Ecological Modelling 176:43-64. 
Appendix 5. Network descriptives of augmented FCM (1), regional FCM (1), local FCMs (4) representing the wildfire system in the Chiquitania.

\begin{tabular}{|c|c|c|c|c|c|c|}
\hline & Augmented $\dagger$ & Regional & & Concepción & & Roboré \\
\hline & & Experts & Ranchers & Communities & Authorities & Authorities \\
\hline Nodes & 36 & 33 & 25 & 22 & 29 & 20 \\
\hline Edges & 110 & 87 & 52 & 39 & 58 & 47 \\
\hline Edge/node & 3.1 & 2.6 & 2.1 & 1.8 & 2.0 & 2.4 \\
\hline Densitył & 0.09 & 0.08 & 0.09 & 0.08 & 0.07 & 0.12 \\
\hline Central nodes§ & 4 & 5 & 3 & 3 & 3 & 2 \\
\hline Transmitters| & 11 & 11 & 11 & 10 & 11 & 9 \\
\hline Receiversף & 4 & 4 & 3 & 3 & 3 & 3 \\
\hline Complexity\# & 0.36 & 0.36 & 0.27 & 0.30 & 0.27 & 0.33 \\
\hline Edge weight†† & 0.33 & 0.55 & 0.65 & 0.67 & 0.62 & 0.79 \\
\hline Hierarchyキキ & 0.01 & 0.02 & 0.03 & 0.03 & 0.02 & 0.09 \\
\hline
\end{tabular}

† augmented network integrates regional FCM and the 3 FCMs constructed in Concepción; $¥$ measured as $\mathrm{E} / \mathrm{N}(\mathrm{N}-1)$ where $\mathrm{E}$ is number of edges and $\mathrm{N}$ number of nodes; $\S$ sum of in degree and out degree based on absolute values (upper percentile); $\mid$ zero in degree, or high out degree to in degree ratio (upper percentile); I zero out degree, or high in degree to out degree ratio (upper percentile); \# measured as the ratio of receivers to transmitters; $†+$ average weight of absolute edge values in the network; $¥ \ddagger$ hierarchy index $h$ (MacDonald 1983) 


\section{Appendix 6. Networks showing the FCMs developed in focus groups.}

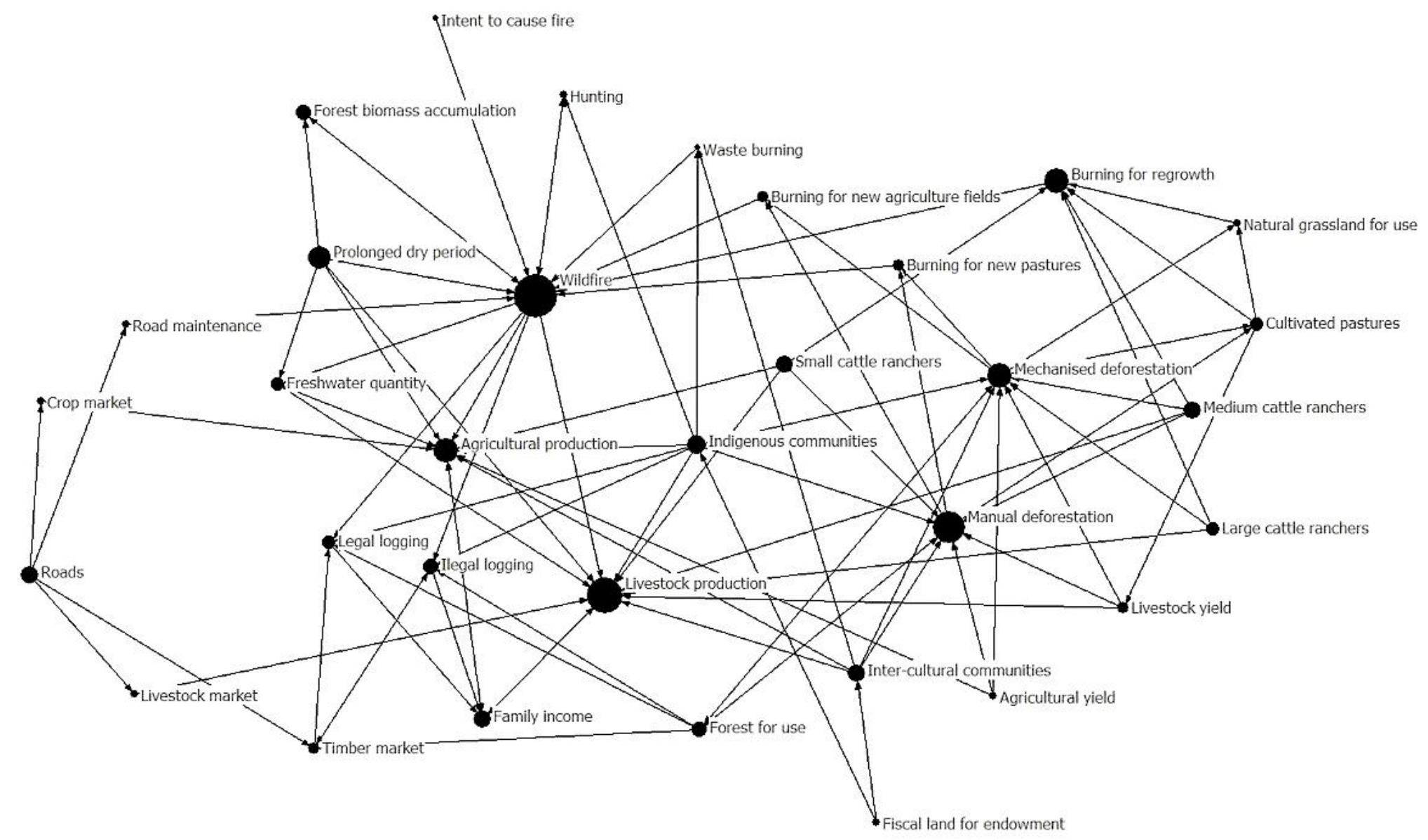

Fig. A6.1. Network showing the regional experts' FCM. Variables with higher degree centrality are presented as larger nodes. Edge weights are not visualized to help readability. 


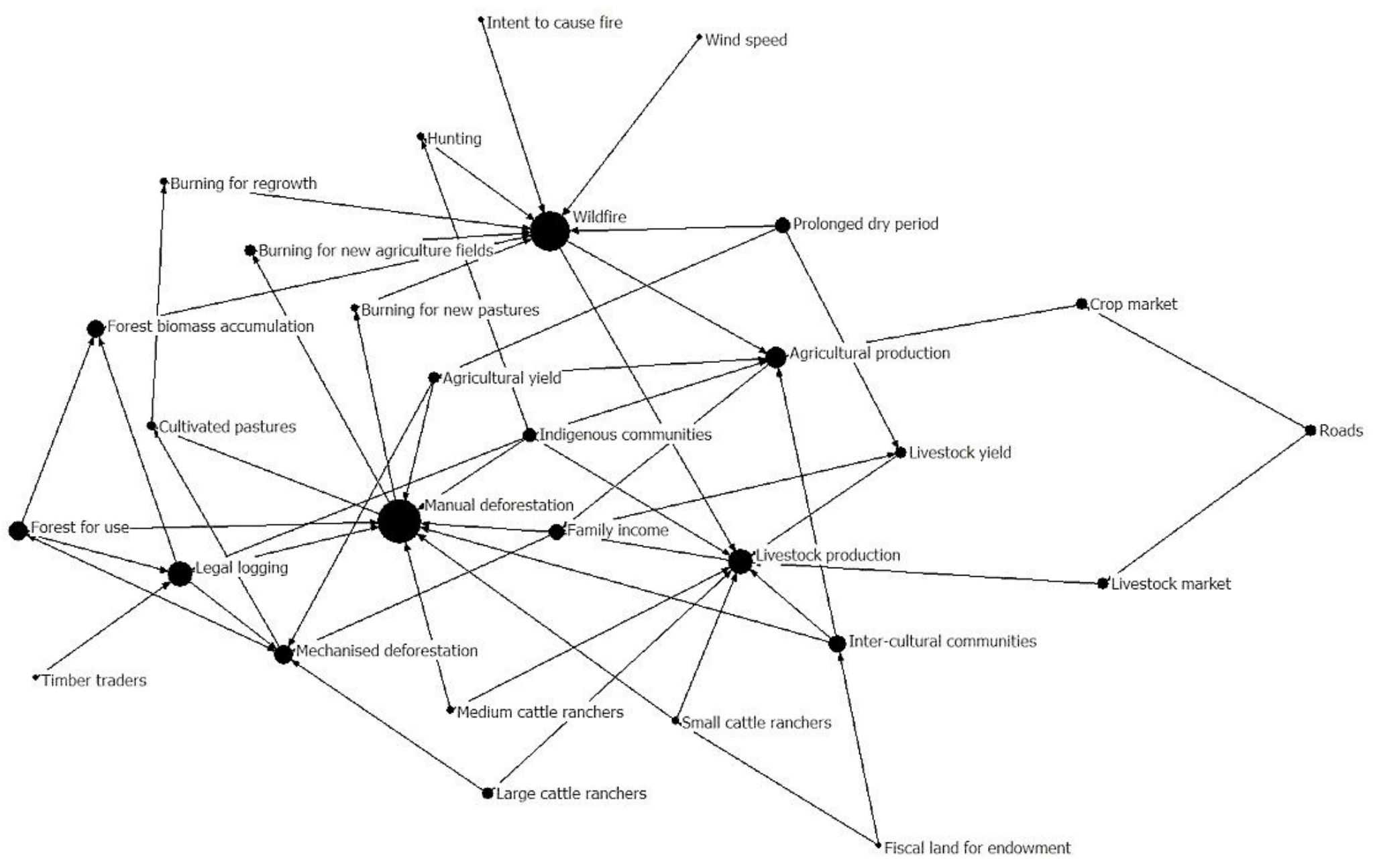

Fig. A6.2. Network showing the FCM developed in Concepción by the local authorities. Variables with higher degree centrality are presented as larger nodes. Edge weights are not visualized to help readability. 


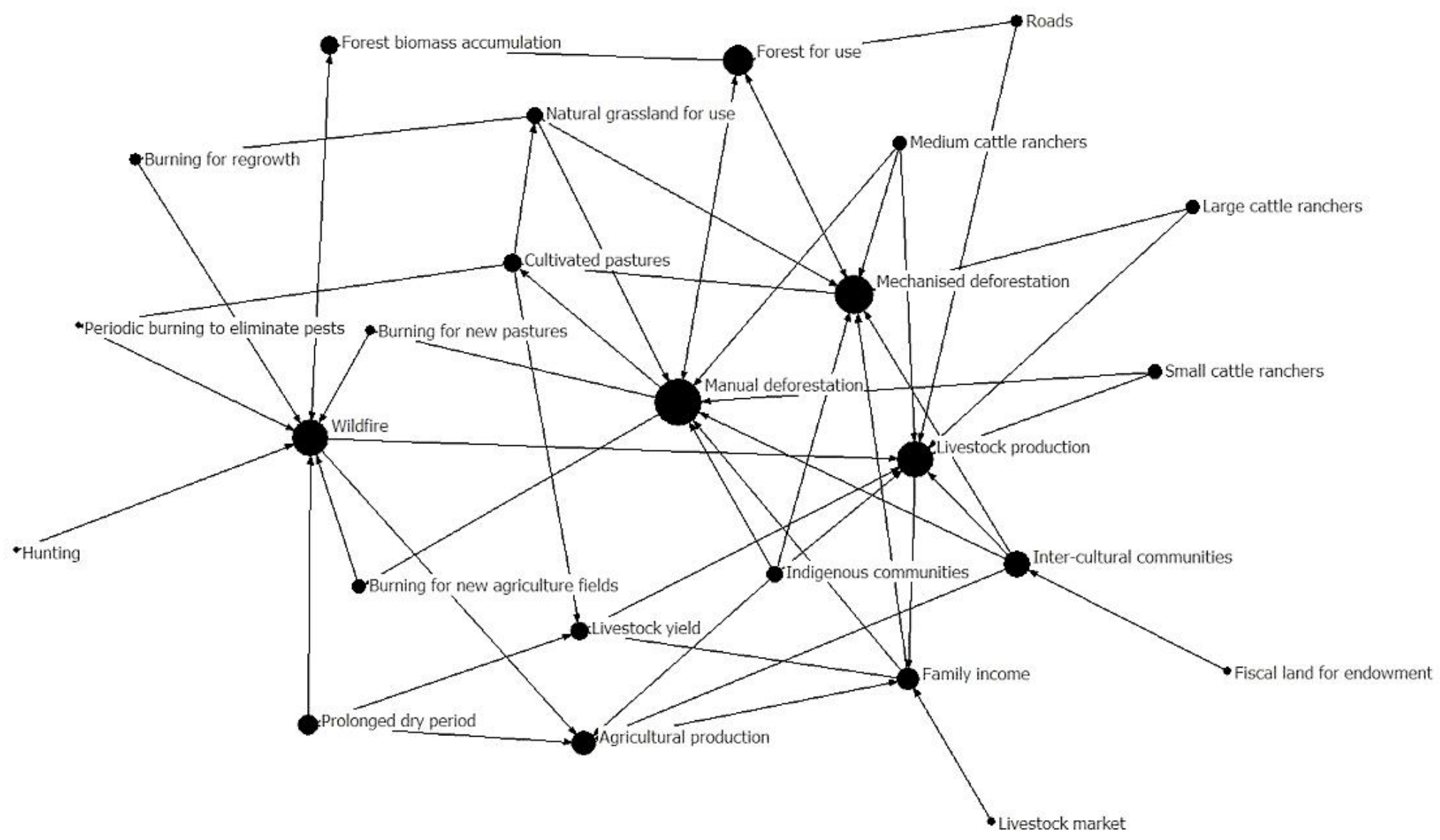

Fig. A6.3. Network showing the FCM developed in Concepción by the cattle ranchers. Variables with higher degree centrality are presented as larger nodes. Edge weights are not visualized to help readability. 


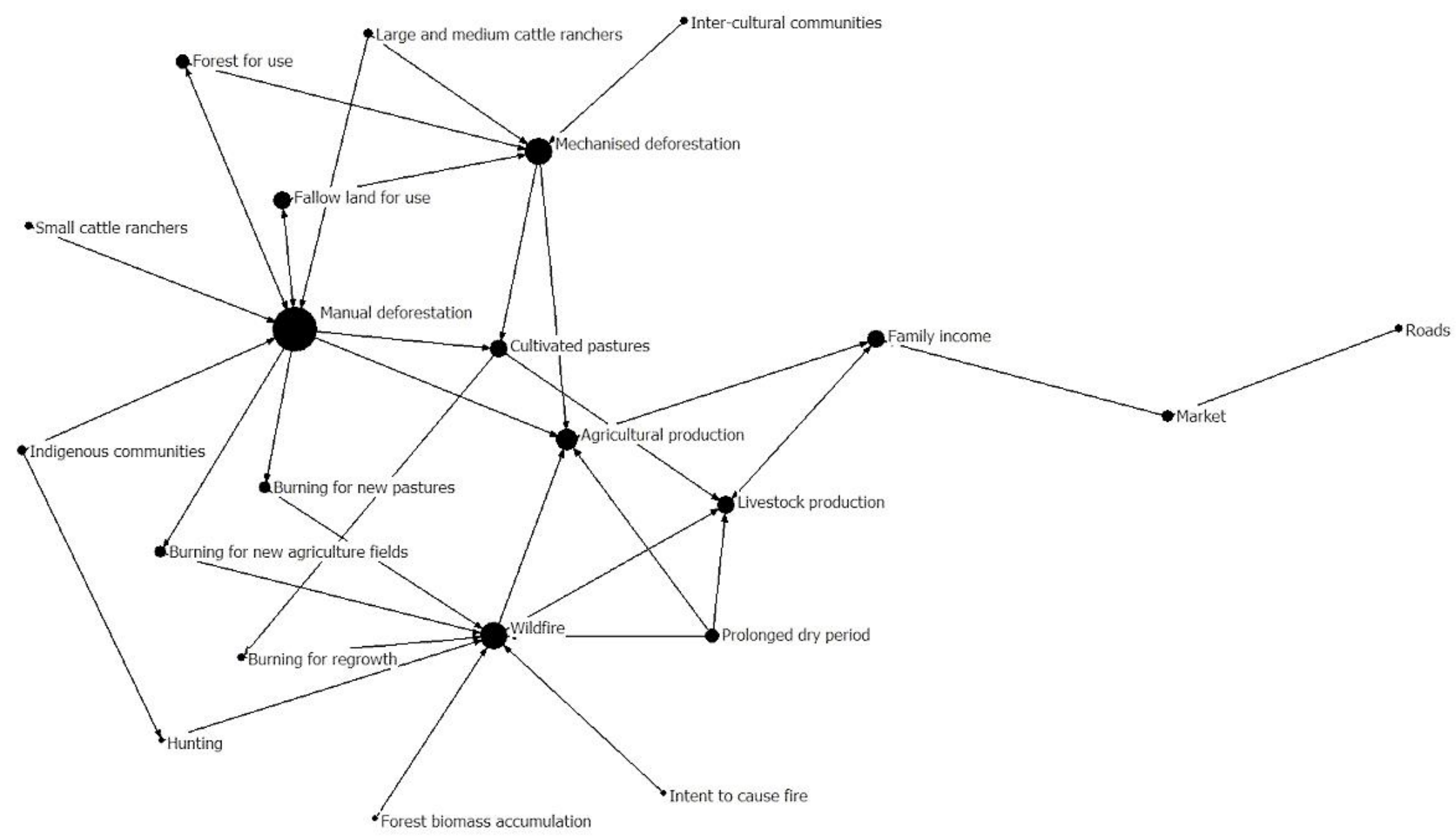

Fig. A6.4. Network showing the FCM developed in Concepción by the local communities. Variables with higher degree centrality are presented as larger nodes. Edge weights are not visualized to help readability. 